\title{
Manoel Correia Defreitas na literatura sobre o Contestado
}

\author{
Ana Crhistina Vanali ${ }^{1}$
}

\begin{abstract}
RESUMO: Manoel Correia Defreitas (1851-1932) foi deputado federal pelo Paraná nas legislaturas de 1909 a 1914. Durante o ano de 1914 visitou os redutos de Taquaruçu e Caraguatá na tentativa de convencer os moradores desses redutos a se dispersarem e evitar o ataque das forças oficiais. Essa visita ficou conhecida como CAMPANHA HUMANITÁRIA na imprensa curitibana e MISSÃO REPUBLICANA DE PAZ na literatura em geral. Correia Defreitas foi acompanhado de Antonio da Rocha Tico (fazendeiro gaúcho estabelecido em Jaguaraíva e que era representante do jornal Diário da Tarde de Curitiba). Poucas são as informações específicas sobre essa campanha, assim sendo o trabalho faz uma revisão bibliográfica de como foi analisada a participação de Defreitas na Guerra do Contestado.
\end{abstract}

Palavras-chave: Manoel Correia Defreitas. Guerra do Contestado. Limites PR e SC.

\section{Manoel Correia Defreitas in the Contestado's literature}

\begin{abstract}
Manoel Correia Defreitas (1851-1932) was a federal deputy for Paraná in the legislatures from 1909 to 1914. During the year 1914 he visited the strongholds of Taquaruçu and Caraguatá in an attempt to convince the residents of these strongholds to disperse and to avoid the attack of the Forces. This visit was known as HUMANITARIAN CAMPAIGN in the press in Curitiba and REPUBLICAN MISSION OF PEACE in literature in general. Correia Defreitas was accompanied by Antonio da Rocha Tico (a farmer from Rio Grande do Sul who was established in Jaguaraíva and who was a representative of the newspaper Diário da Tarde in Curitiba). Few are the specific information about this campaign, so the work makes a bibliographical review of how the participation of Defreitas in the Contestado War was analyzed.
\end{abstract}

Keywords: Manoel Correia Defreitas. Contestant War. PR and SC limits.

"Só com reza não adianta

É preciso nóis luta,

Fé e corage ao mesmo tempo Pro inimigo derrubá."

- Enviado em 15/09/2016

- Aprovado em 18/11/2016

\footnotetext{
${ }^{1}$ Doutoranda em Sociologia na Universidade Federal do Paraná. Professora de Sociologia na UTFPR-Campus Curitiba no DAESO (Departamento de Estudos Sociais). E-mail: anacvanali@yahoo.com.br.
} 


\section{INTRODUÇÃO}

A área que foi cenário da Guerra do Contestado entre 1912 e 1916 localiza-se no Meiooeste, Planalto Central e Norte de Santa Catarina, entre os vales dos rios Canoinhas/Leste e do Peixe/Oeste, com os rios Negros e Iguaçu/Norte e o Rio Canoas e Campos Novos/Sul. Mas essa é apenas uma parte da região contestada que se estendia do Extremo-oeste, na fronteira com a Argentina (atuais Oeste Catarinense e Sudoeste Paranaense) e que ficou conhecida como Território Contestado até 1917, quando da homologação do Acordo de Limites entre Paraná e Santa Catarina (THOMÉ, 2005).

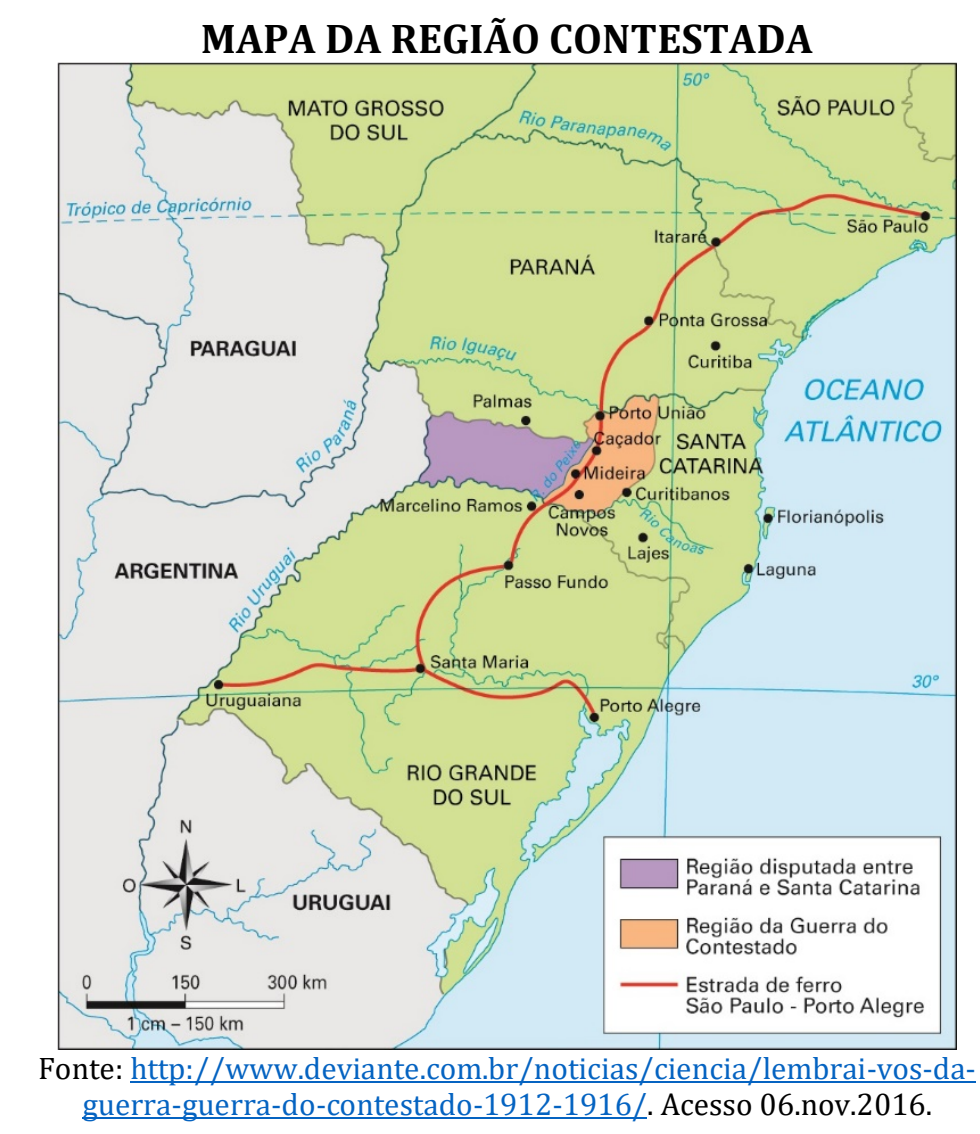

Após quase três anos de conflito, entre dezembro de 1913 e janeiro de 1916, cerca de nove mil militares e civis, entre mortos, desaparecidos, feridos e desertores deram baixa nos campos de batalha da Guerra do Contestado, um dos mais sangrentos da História do Brasil. No auge do conflito, entre o final de 1914 e início de 1915 estavam em ação 8 mil militares, sendo 7 mil soldados das armas da Infantaria, Cavalaria, Artilharia e Engenharia do Exército Brasileiro, 
do Regimento de Segurança do Paraná, do Regimento de Segurança de Santa Catarina e mais mil civis contratados pela União. Do outro lado, havia os sertanejos com o Exército Encantado de São Sebastião, com aproximadamente 10 mil membros composto por homens, mulheres, idosos e crianças, na maioria caboclos luso-brasileiros armados com revólveres, espingardas e facões (THOMÉ, 2005).

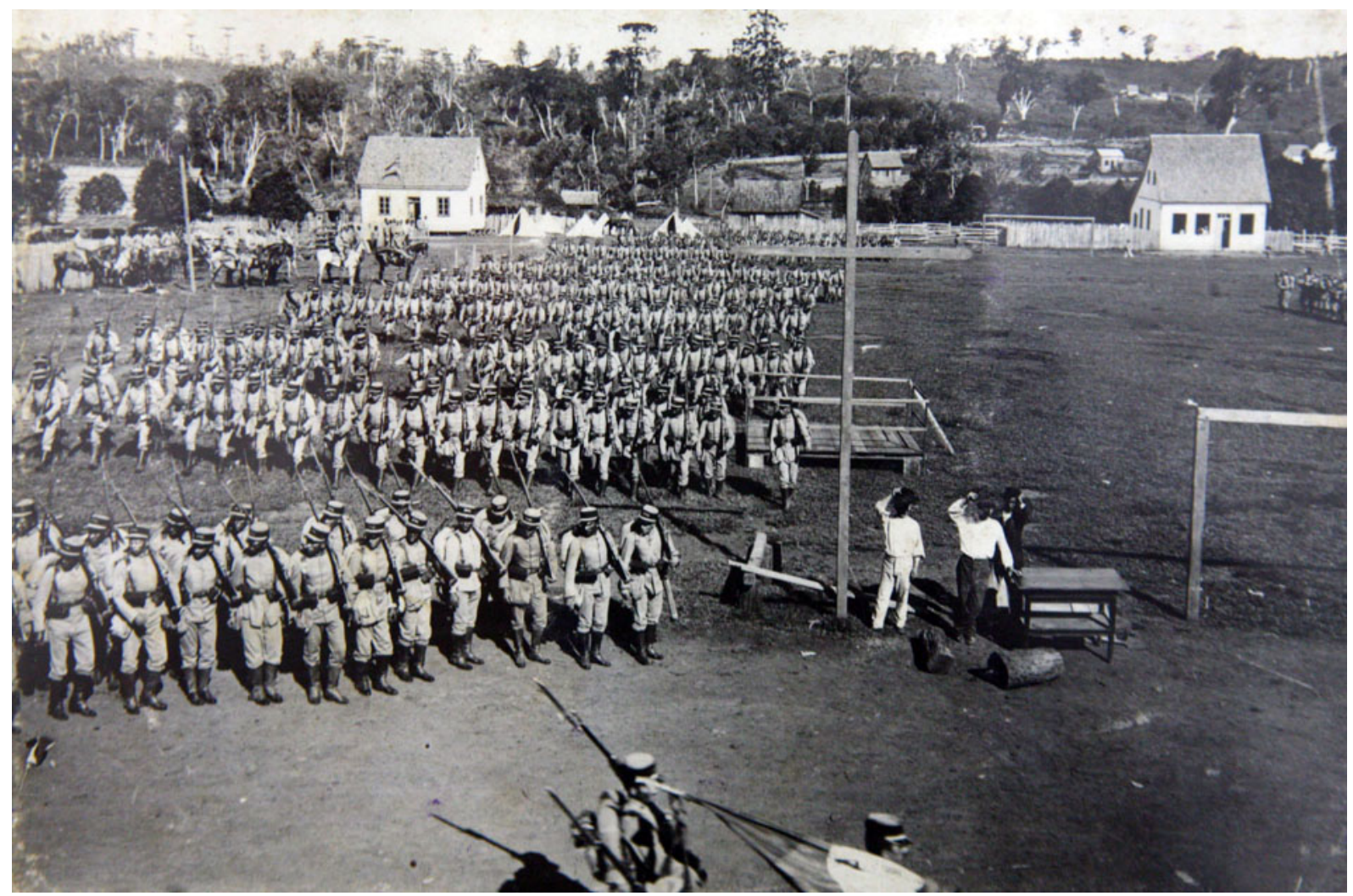

Revista passada pelo general Setembrino de Carvalho, chefe das tropas governamentais, ao 56ํㅡㅁ Batalhão de Caçadores sob o comando do Coronel Onofre Ribeiro em Canoinhas, SC (legenda do álbum original) Fonte: Arquivo Histórico do Exército (RJ) apud Rodrigues (2012, p.5). 


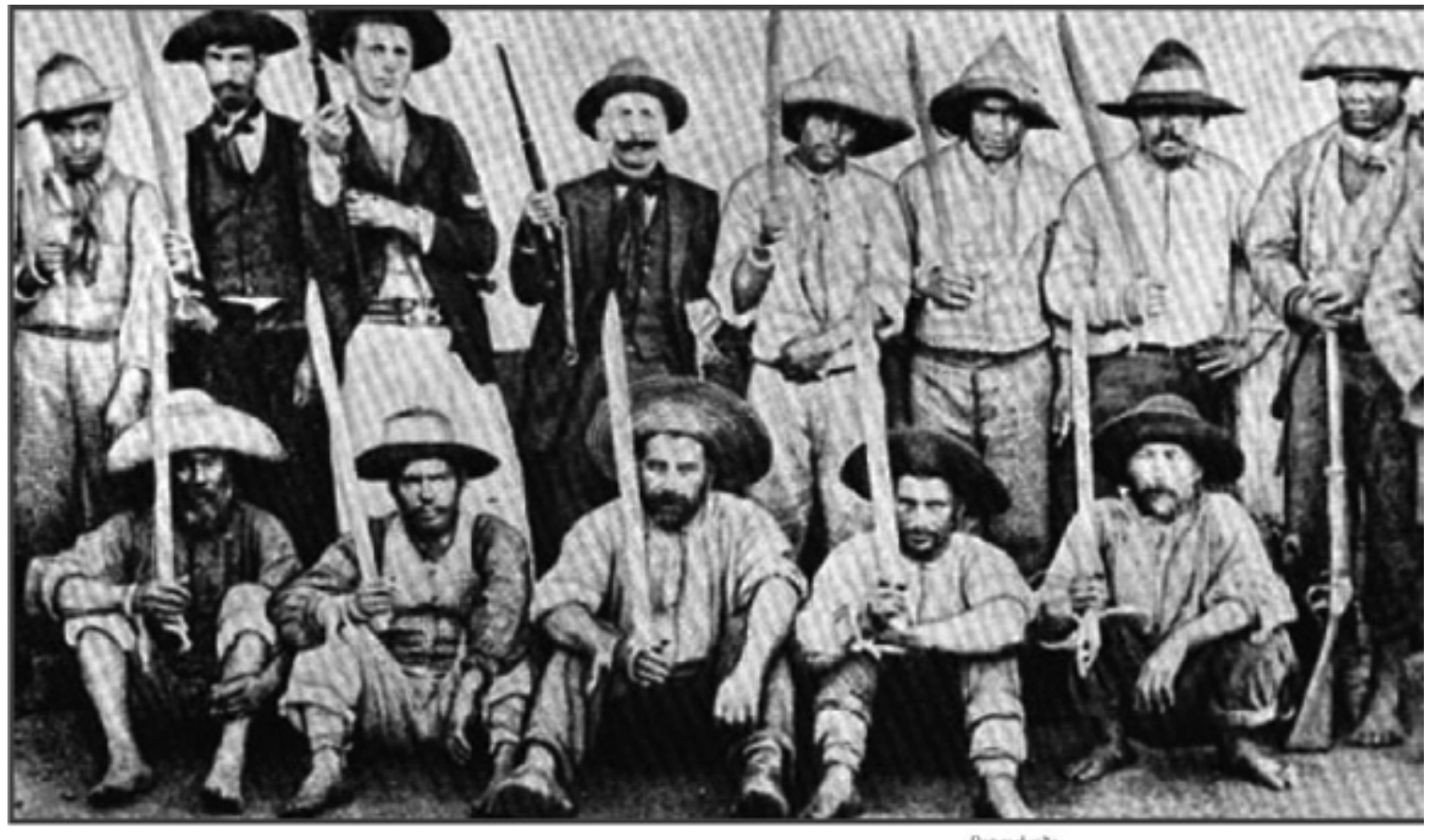

Grupo de rebeldes do Contestado

Rispoodicioto

Pares de São Sebastião

Fonte: Espig (2012).

A questão de limites entre Paraná e Santa Catarina é antiga. Desde a formação do Império Brasileiro, as províncias de São Paulo e Santa Catarina não conheciam seus limites. Em 1853, com a criação da Província do Paraná, desmembrada de São Paulo, abriu-se o debate sobre a linha limítrofe, discussão que passou a ser mais acirrada entre as duas unidades federativas após a implantação da república. A questão envolvia o chamado "Território Contestado", na época sob a administração do Paraná e localizado entre o rio Iguaçu (ao Norte), o rio Uruguai (ao Sul), a Serra Geral (ao Leste) até a fronteira com a Argentina (ao Oeste). Enquanto Paraná e Santa Catarina procuravam encontrar uma solução para o assunto, o Império havia decidido em 1879 que provisoriamente caberia ao Paraná administrar as terras ao Oeste do Rio do Peixe. Em 1900, o governo catarinense entrou com uma ação judicial contra o Estado do Paraná no Supremo Tribunal Federal reclamando seus direitos sobre todo o território. Em 1904, o STF manifestou-se oficialmente a favor de Santa Catarina, decisão confirmada em 1909 e ratificada em 1910, determinando que os paranaenses entregassem a administração das terras aos catarinenses. 0 governo do Paraná apoiado pela população, rebelou-se e não acatou a decisão, o que gerou um impasse jurídico-administativo no país (CARDOSO, 2014).

$\mathrm{Na}$ disputa por limites três confrontos importantes antecederam a Guerra do Contestado. 0 primeiro foi entre dezembro de 1905 e janeiro de 1906 na Vila de Nova Timbó 
quando Demétrio Ramos (ex-maragato e primo do governador de Santa Catarina Vidal Ramos) depois de se desentender com o Capitão Fabricio Vieira (ex-pica-pau) enfrentou as forças policiais do Paraná e um destacamento do exército. 0 segundo foi em setembro de 1909 quando o Coronel Aleixo Gonçalves de Lima (ex-maragato) comandando 500 homens da Guarda Nacional invadiu uma área que o Paraná dizia ser sua na Estrada Dona Francisca, expulsando a força policial paranaense que protegia uma barreira de impostos próxima à São Bento. A terceira foi em outubro de 1912 na cidade de Irani. O governo do Paraná entendeu como uma invasão catarinense a presença de um grupo de pessoas que acompanhavam o monge José Maria e mandou o Regimento de Segurança para enfrentá-lo. Nesse episódio conhecido como Combate de Banhado Grande faleceu o Coronel João Gualberto e o monge José Maria.

Transcorria o segundo semestre de 1913 e nos tribunais superiores e nas tribunas legislativas a questão dos limites entre Paraná e Santa Catarina continuava sendo discutida. Em 15 de dezembro de 1913 na região de Taquaruçu chegaram as forças militares federais e policiais, mas como não agiram em sincronia, os caboclos conseguiram reagir e derrotaram as tropas oficiais. Estava iniciada a Guerra do Contestado. Nos primeiros dias de janeiro de 1914, na vila de Curitibanos é assassinado, pelo superintendente local, Praxedes Gomes Damasceno (líder comunitário de Taquaruçu) quando tentava recuperar uma tropa de mulas cargueiras apreendidas. Como consequência o Frei Rogério Neuhaus, que tentava dissuadir os ajuntados, é expulso do reduto em que se encontrava. 0 governo de Santa Catarina fez novo apelo ao exército que reuniu uma tropa de aproximadamente 750 homens, sob o comando do Tenente-coronel Dinarte de Aleluia Pires, com ordens de efetuar um ataque implacável (CARDOSO, 2014).

Diante do constatado poderio militar, os caboclos decidiram se retirar de Taquaruçu em direção a Caraguatá. Na noite de 8 de fevereiro de 1914 iniciou o cerrado bombardeio e os caboclos partem deixando poucos combatentes que são dizimados na manhã seguinte. Dias antes, "antecedendo o embate, o deputado federal paranaense Manoel Correia de Freitas, de tendências socialistas ${ }^{2}$, esteve no reduto tentando negociar, sem sucesso, a dispersão dos revoltosos" (TOKARSKI, 2002, p.50).

\footnotetext{
${ }^{2}$ A descrição de Manoel Correia Defreitas como adepto de "ideias socialistas" é dada no sentido dele ser contra a postura conservadora e hegemônica das elites que ocupavam o cenário político da Primeira República. As narrativas biográficas de Correia Defreitas o descrevem como uma figura visionária, despojada e mal compreendida em seu tempo justamente por ter uma visão diferenciada perante as questões sociais, políticas e econômicas. Se Correia Defreitas estivesse presente e atuando hoje na sociedade brasileira, ano de 2016, seria apontado como "comunista", assim como toda pessoa que defende ideias por uma sociedade menos desigual, numa total confusão de conceitos, ideologias e ideias.
} 
Em 20 de outubro de 1916, no Rio de Janeiro, os governadores do Paraná e Santa Catarina assinaram o "Acordo de Limites" dividindo o Território Contestado. Após a homologação pelos legislativos estaduais ${ }^{3}$, os catarinenses assumiram a administração de 28 mil $\mathrm{km}^{2}$ e o Paraná 20 mil km², dos 48 mil km² contestados.

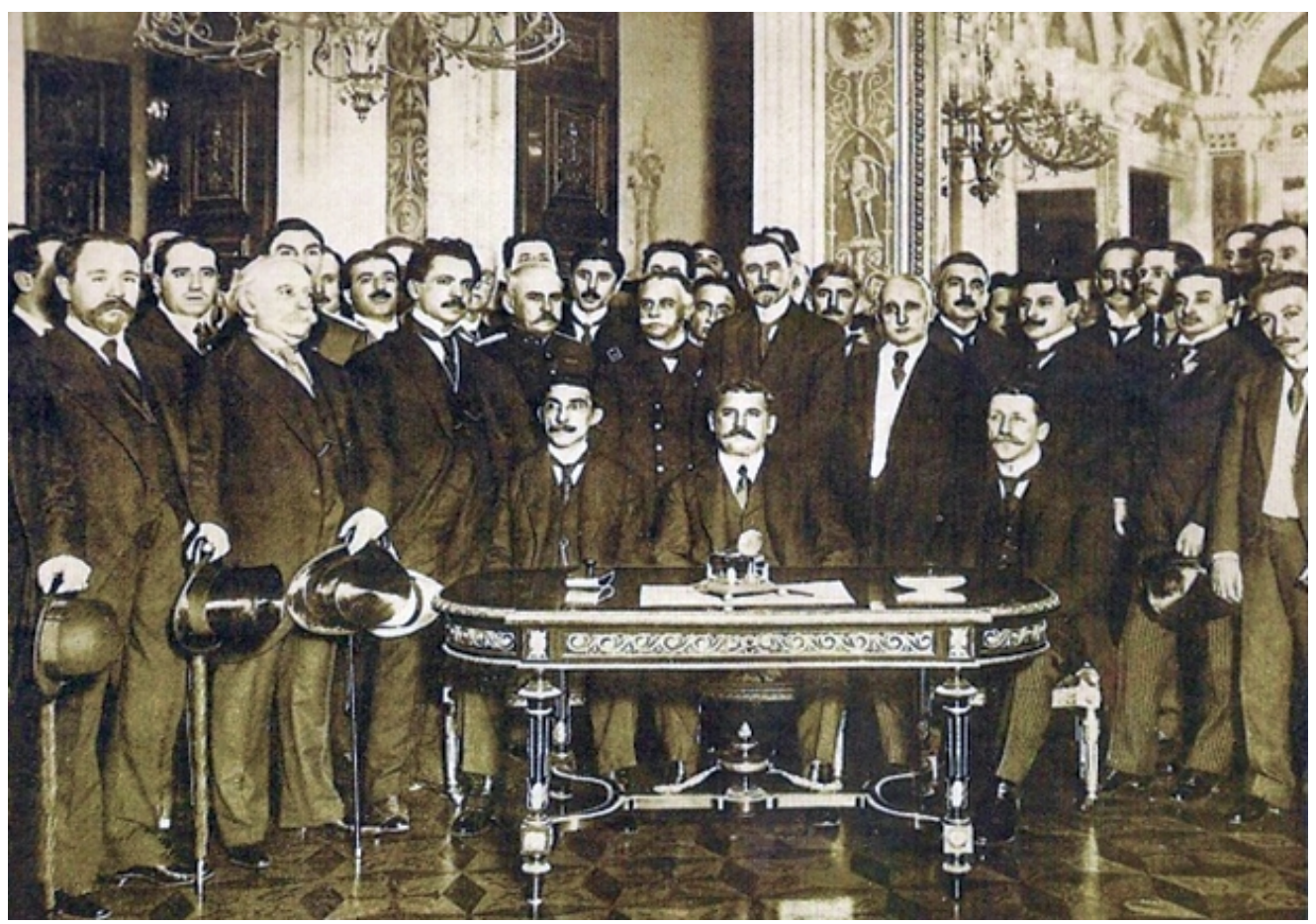

Reunião no Palácio do Catete, em 20 de outubro de 1916 quando foi assinado o tratado que solucionou a questão de limites no Contestado. Na foto, sentados, o Presidente Wenceslau Braz, no centro, ladeado pelos governadores do Paraná (esquerda) e Santa Catarina (direita). Fonte: Disponível em http://www.ivopitz.pro.br/?arquivo=texcontestado. Acesso 06.nov.2016

\section{CORREIA DEFREITAS NA LITERATURA SOBRE 0 CONTESTADO}

\footnotetext{
3 Em 23 de fevereiro de 1917 a Assembleia Legislativa do Paraná, presidida por Trajano Reis, reconheceu o acordo de divisas entre o estado e Santa Catarina, celebrado em 20 de outubro de 1916 no Rio de Janeiro e que oficialmente encerrou a Guerra do Contestado. O reconhecimento foi dado através da Lei № 1653 pelo governador Affonso Alves de Camargo que extinguiu os municípios de Itaiópolis, Três Barras e Vila Nova do Timbó, bem como todas as exatorias estaduais paranaenses que em função do acordo de divisas passaram ao território de Santa Catarina (TOKARSKI, 2002, p.57-58).
} 
Muitos estudos analisam a participação do deputado federal paranaense Manoel Correia Defreitas na Guerra do Contestado. 0 deputado empreendera uma longa e cansativa viagem do Rio de Janeiro até os redutos de Taquaruçu e Caraguatá, permanecendo na região por 19 dias com o objetivo de convencer os sertanejos a dissolver a comunidade da Cidade Santa em nome da paz ${ }^{4}$. Diante da impossibilidade de apresentarmos aqui todos os trabalhos que tratam da missão republicana de paz da qual Correia Defreitas participou, faremos uma breve apresentação dos autores já conhecidos e clássicos e algumas obras de produção mais recente (SANTOS, 2006).

O primeiro trabalho a falar da sua presença em terras contestadas foi Mauricio Vinhas de Queiroz (1977, p.126-150) ${ }^{5}$ que dedica duas seções do seu livro para relatar a passagem do deputado paranaense pelos redutos de Taquaruçu e Caraguatá. Até a obra de Queiroz, os estudos sobre o Contestado eram marcados por uma barreira cultural que impedia o verdadeiro entendimento da vida, da cultura e das ações da população sertaneja. A própria expressão "fanáticos" utilizada para se referir à população sertaneja desqualificava a ação desses sujeitos que somente eram vistos em seu abandono e ignorância, não se procurava entender as suas razões e os poucos autores que tentaram ver o ponto de vista dos sertanejos ainda possuíam sua visão marcada por esse preconceito. Com a obra de Queiroz essa visão estereotipada começou a ser derrubada. Ele empregou o conceito de messianismo para explicar a expressão cultural e social sertaneja e associou o movimento sertanejo à crise social no planalto, à questão de terras e ao abuso dos coronéis/grandes fazendeiros. Entretanto, para o autor o movimento do Contestado ainda era uma "revolta alienada" que revelava um isolamento dos sertanejos em relação à sociedade circundante 6 .

Com o título “A missão Correia de Freitas”, Queiroz (1977, p.126) começar a tratar da presença do deputado do Paraná na Guerra do Contestado. Após uma brevíssima biografia7,

${ }^{4}$ Ver Cronograma das missões pacifistas na Região do Contestado do final do artigo.

${ }^{5}$ A primeira edição dessa obra é de 1966 pela Civilização Brasileira.

${ }^{6}$ A grande virada interpretativa acontece com a obra de Duglas Teixeira Monteiro (Os Errantes do Novo Século. São Paulo: Duas Cidades, 1974).

7 Biografia baseada na obra de SOTTOMAIOR, Sebastião Paraná de Sá (1922). Galeria Paranaense: notas biográficas. Curitiba: [s.e] 
indica que em fevereiro de $1914^{8}$ Correia Defreitas seguiu para o Reduto de Taquaruçu com o objetivo de conversar com os sertanejos. Ele foi acompanhado do coronel Antonio Maria da Rocha Tico ${ }^{9}$ e pelo guia Antonio Cordeiro Sampaio ${ }^{10}$. Quando estava adiante de Curitibanos foram alcançados pelas tropas legais e Correia Defreitas teve um encontro com o TenenteCoronel Dinarte de Aleluia Pires ${ }^{11}$ no qual entregou uma carta de Lebon Regis ${ }^{12}$, o que demonstrava que sua missão tinha apoio oficial. Correia Defreitas solicita ao comandante das forças legais, Aleluia Pires, não atacar o reduto antes de seu regresso, pois sua missão era tentar fazer a dissolução dos sertanejos de forma pacífica. 0 comandante aceita aguardar o resultado das negociações. Correia Defreitas e comitiva passam dois dias no reduto de Taquaruçu. Foram recebidos com muita hospitalidade, tomaram muito chimarrão em diferentes casas e

${ }^{8}$ Ver cronograma da missão pacifista de Manoel Correia Defreitas na região do Contestado ao final do artigo.

${ }_{9}^{9}$ Antonio Maria da Rocha Tico (1863-1929) era um fazendeiro gaúcho estabelecido em Jaguaraíva/PR e que atuou como representante do jornal Diário da Tarde, de Curitiba, na campanha humanitária promovida por esse periódico no início do ano de 1914 (Diário da Tarde de 22/01/1914). No início do século XX cresce a necessidade de agilidade na movimentação das tropas militares para evitar uma eventual ação por parte da Argentina sobre o território brasileiro. O governo então decide construir a ferrovia ligando São Paulo ao Rio Grande do Sul. Com a construção, Jaguariaíva recebe maçons, que fundam uma das mais fortes entidades da história do município. A história da maçonaria em Jaguariaíva começa com a Loja Maçônica José de Carvalho, fundada em 2 de agosto de 1902, tendo como um dos membros fundadores Antônio Maria da Rocha (Maçonaria faz 100 anos em Jaguariaíva, Tribuna do Paraná, 14/08/2002 e Esphynge de Novembro de 1902). Coronel Antônio Maria da Rocha (Tico) era casado com Luiza da Silva Rocha. Naturais da cidade de Taquari/RS. Tiveram 11 filhos. Eram proprietários de grandes fazendas no Estado do Rio Grande do Sul e do Paraná. Tico tinha a patente de Coronel da Guarda Nacional obtida na vigência do $2^{\circ}$ Império. Luiza da Silva Rocha era sobrinha do Barão de Antonina, João da Silva Machado, primeiro Senador da Província do Paraná, vigência do Império, precursor da Emancipação Política e Econômica da 5á Comarca de São Paulo em 1843, que se tornou então a Província do Paraná e mais tarde no Estado do Paraná e, do seu irmão Francisco de Paula e Silva, o Barão de Ibicuí (Origem da Família Nunes Rocha disponível em http://escritosanalfabetos.blogspot.com.br/2009/01/origem-da-familia-nunes-rocha.html. Acesso 06/11/2016). Tico faleceu em 22 de outubro de 1929 na cidade de Curitiba, com 66 anos. Era filho de João Maria da Rocha. Sua última ocupação era como coletor estadual em Wenceslau Brás (A República de 23/10/1929).

10 Segundo o jornal A Regeneração de 26/09/1878 Antonio Cordeiro Angelo era fazendeiro em Lages/SC.

11 Dinarte de Aleluia Pires

12 Gustavo Lebon Regis (1874-1930) filho de Alexandre Justino Regis e de Luísa Lebon Regis nasceu na cidade de Parati, atual Araquari (SC). Em 1894, como alferes-aluno da Escola Militar, tomou parte no combate à Revolução Federalista na cidade de Lapa (PR). Em 1902 formou-se, obtendo os diplomas de engenheiro militar e de bacharel em matemática. Iniciou a carreira política como deputado estadual em Santa Catarina na legislatura $1902-1903$. Reeleito para quatro mandatos consecutivos, em 1910 participou da Assembleia Constituinte de Santa Catarina e em 1912 foi presidente da ALESC. Entre os anos de 1911 e 1912 ocupou interinamente o cargo de prefeito de Florianópolis em três ocasiões. Foi também secretário da Fazenda, Viação e Obras Públicas e Agricultura do Estado de Santa Catarina de janeiro de 1913 a outubro de 1914, época da Comitiva Republicana de Paz da qual Manoel Correia Defreitas participou. Em 1915 foi eleito deputado federal por Santa Catarina. Durante sua passagem pela Câmara dos Deputados, de 1915 a 1917, integrou a Comissão Demarcadora de Limites entre os Estados de Santa Catarina e Paraná, formada após a Guerra de Contestado (1912-1916). Como militar, foi sucessivamente promovido, de alferes comissionado, em 1894, até obter a patente de coronel efetivo, em 1923. Faleceu na cidade do Rio de Janeiro (Piazza, 1985). 
pernoitaram na casa do falecido Praxedes Gomes Damasceno ${ }^{13}$. Correia Defreitas não consegue sucesso em suas negociações para dispersar os sertanejos. Foi informado que os líderes que poderiam ordenar a dispersão haviam partido para o Reduto de Caraguatá. Correia Defreitas decide ir à Caraguatá. 0 coronel Antonio Maria da Rocha Tico vai para Campos Novos e passa telegramas ao jornal Diário da Tarde dando pormenores da missão ao Reduto de Taquaruçu e o guia Antonio Cordeiro Sampaio vai para Espinilho (lugar de concentração das tropas legais) e fornece depoimento ao Henrique Rupp Júnior ${ }^{14}$. Queiroz (1977, p.127) comenta sobre uma carta de Correia Defreitas em que ele descreveu o que viu em Taquaruçu, mas até o momento não conseguimos localizar esse material. Os três: Correia Defreitas, Tico e Sampaio, fornecem detalhes da organização, do número de pessoas, do número de armas, das lideranças e da crença dos sertanejos. Toda vez que Correia Defreitas mencionava a questão da dispersão, os sertanejos respondiam que eles estavam concentrados ali numa santa missão e que não pretendiam atacar ninguém, a não ser que fossem atacados pois teriam que se defender (Diário da Tarde de 06/03/1914).

13 Praxedes Gomes Damasceno (Xandoca), líder comunitário de Taquaruçu, foi assassinado nos primeiros dias de janeiro de 1914, na vila de Curitibanos, pelo Superintendente local, quando tentava recuperar uma tropa de mulas cargueiras apreendidas (Disponível em http://nilson-contestado.blogspot.com.br/2007/05/breve-histria-daguerra-do-contestado_31.html. Acesso em 06.nov.2016).

${ }^{14}$ Henrique Rupp Junior (1880-1959) foi advogado, jornalista, empresário e político. Filho de Henrique Rupp e Ema Rupp. Foi deputado à Assembleia Legislativa de Santa Catarina na 6 6 $^{\mathrm{a}}$ legislatura (1907 - 1909), na 10 $\underline{\text { a }}$ legislatura (1919 - 1921) e na 11 a legislatura (1922 - 1924). Foi um dos organizadores da Aliança Liberal em Santa Catarina, mas depois afastou-se do grupo organizado em torno de Getúlio Vargas após a Revolução de 1930. Foi promotor público primeiro em Curitibanos; logo depois em Florianópolis. Juntamente com \osé Boiteux, Henrique Fontes e Gil

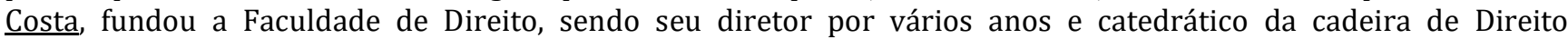
Comercial. Foi deputado Federal, participante ativo da revolução de 30 e um dos fundadores da UDN, em 1945 (Piazza, 1985). 


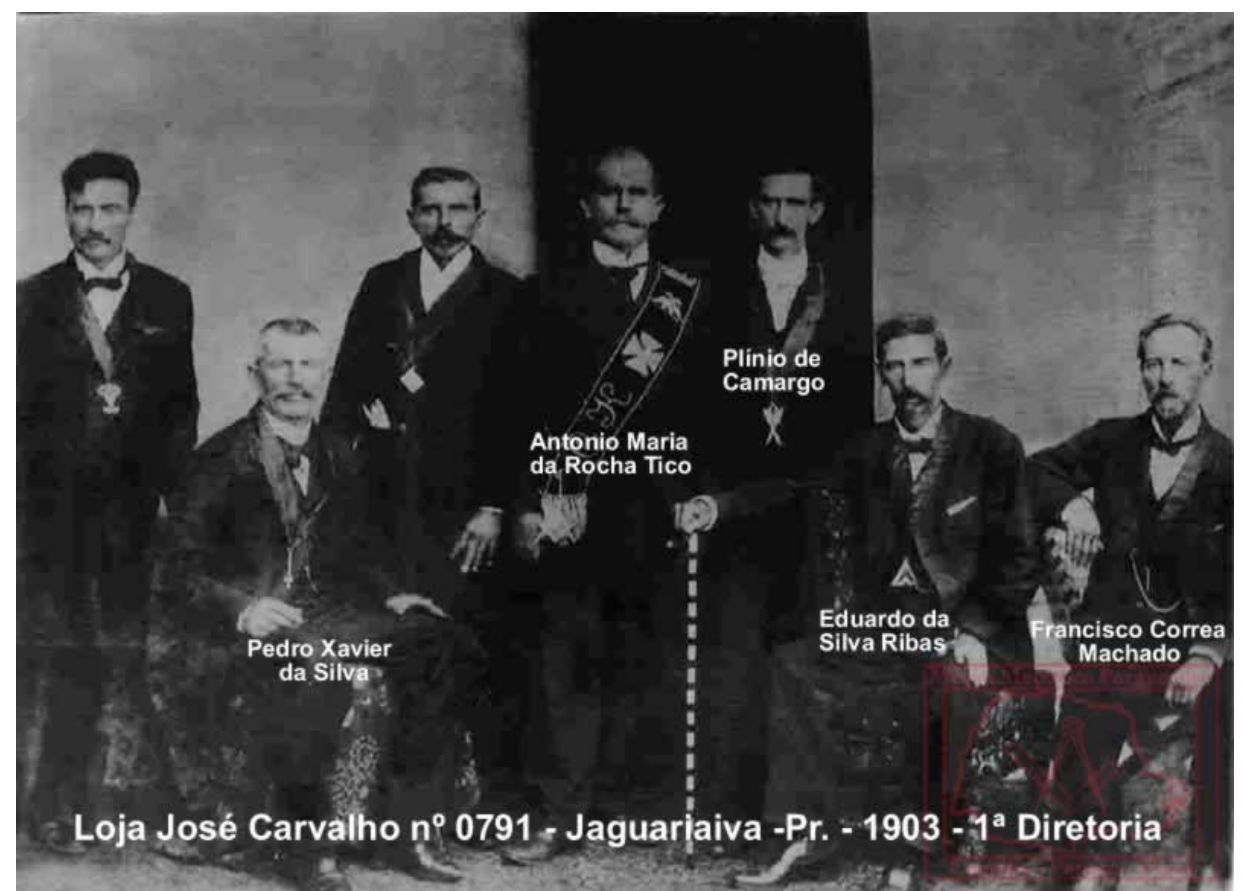

Ao centro o Coronel Antonio Maria Rocha Tico, emissário do Diário da Tarde Fonte: http://www.museumaconicoparanaense.com. Acesso em 03.nov.2015

A segunda seção dedicada ao deputado paranaense intitula-se "Correia de Freitas em Caraguatá" (Queiroz, 1977, p.147). O autor aponta que em sua missão no Reduto de Taquaruçu, Correia Defreitas conseguiu deles a promessa que se dispersariam desde que os chefes dos redutos de Taboão e Caragatá também concordassem (Diário da Tarde, 13/02/1914). Por esse motivo seguiu diretamente de Taquaruçu para Caraguatá, pois achava que conseguiria uma pacificação geral antes do ataque das forças legais, evitando o massacre dos sertanejos. Apesar de seus esforços em Caraguatá para estabelecer um acordo que pusesse fim ao movimento, as tropas legais não aguardaram seu retorno e atacaram o Reduto de Taquaruçu no dia 8 de fevereiro de 1914. Correia Defreitas chegou em Campos Novos dia 10 de fevereiro e de lá partiu para Porto Alegre, continuando viagem para a Argentina, retornando meses depois quando a situação da Guerra do Contestado havia totalmente se modificado. Assim pouco se sabe das negociações que fez em Caraguatá e dos detalhes da organização desse reduto. Em seu depoimento para o jornal Diário da Tarde de 11 de fevereiro de 1914 demonstra o sentimento de inutilidade de todos os esforços que empreendera visando a pacificação.

Existe uma versão que atribui a Correia Defreitas, quando da sua estada em Caraguatá, da oferta de cem mil contos de réis para que os sertanejos se dispersassem, porém, eles teriam 
exigido um milhão de contos de réis e a restauração da monarquia, condições fora do alcance do deputado paranaense. Em outra versão Correia Defreitas teria garantido que o governo daria terras aos sertanejos, mas os sertanejos responderam que só desejavam a monarquia. Esta última versão em que não se fala em dinheiro, mas na distribuição de terras foi incorporada ao folclore e aparecia cantada em trovas:

\footnotetext{
Ele era emissário Que o governo mandava Ia saber dos jagunços Por que se revoltava. Se era para mode terra 0 governo dava.

Só aceitamos monarquia Se for possível nos dar Que aqui nesse regimento É a lei que há de ficar (Queiroz, 1977, p.147) ${ }^{15}$
}

Seja qual for a versão, todas convergem num ponto: o retorno da monarquia como condição de paz. 0 retorno da monarquia não era o retorno de algum descendente de Dom Pedro II ao poder, mas sim a derrubada do governo dos coronéis e a implantação de um governo mais justo. Para o autor, quando Correia Defreitas procurou negociar em Caraguatá, a reivindicação por terras não era mais a exigência imediata dos sertanejos, mas sim a mudança da forma de governo, o que inviabilizou os projetos pacifistas do deputado paranaense. As reivindicações dos sertanejos saíram do plano do possível como terras, escolas, dinheiro para um plano irrealizável. Para Queiroz (1977) Correia Defreitas experimentou uma grande decepção.

Depois da obra de Queiroz (1977) outros trabalhos também trataram da missão pacifista de Correia Defreitas na Guerra do Contestado. Fernando Osvaldo de Oliveira (1978) apontada o deputado paranaense como o emissário do governo que trazia a palavra do presidente da república (na época Marechal Hermes da Fonseca). 0 conselho era para que os chefes debandassem e não reunissem as pessoas nos redutos porque senão o governo teria que destruí-los. A resposta foi negativa e alegavam que eram pacíficos, que apenas se defendiam, pois, as "tropas do Hermes é que vinham provocá-los". Como haviam conseguido uma vitória no primeiro combate ${ }^{16}$, a posição das lideranças era irredutível, pois achavam que iriam repetir o

\footnotetext{
15 Conforme arquivo do autor. NÊNE CHEFRE. Sebastião Antunes de Oliveira, vulgo Nêne Chefre. "Os jagunços". Lebon Regis, 1943.

16 Taquaruçu em dezembro de 1913.
} 
feito. 0 autor aponta que o deputado do Paraná ofereceu terras nas negociações e tentava mostrar a impossibilidade deles saírem vitoriosos. Os chefes dos sertanejos procuravam protelar as negociações com o deputado paranaense pois haviam recebido a notícia dos seus informantes que as tropas estavam esperando a volta do deputado para atacar. As negociações continuavam e Correia Defreitas agora prometeu dinheiro e ajeitar as terras depois (Oliveira, 1978, p.73-78). 0 autor não acrescenta nada de novo em relação ao trabalho de Queiroz. Também não cita o nome do deputado Correia Defreitas, apenas fala "o deputado do Paraná" e não aponta o momento em que Correia Defreitas estaria negociando em Taquaruçu ou em Caraguatá.

Marli Auras (1984, p.84) faz uma referência muito rápida à missão pacifista de Correia Defreitas. Para a autora enquanto o Estado organizava uma nova investida contra os sertanejos, o deputado pelo Paraná, Correia Defreitas, defensor de ideias socialistas, se deslocou até o Reduto de Taquaruçu a fim de conseguir a dispersão dos sertanejos sem derramamento de sangue. Ficou dois dias nesse reduto e partiu para o de Caraguatá. Finaliza essa primeira parte apontando para uma questão: o deputado do Paraná não conseguiu atingir seu objetivo pela fé do caboclo ser muito sólida ou porque seu trabalho foi atropelado pela ação precipitada das tropas legais? Depois faz menção a passagem do deputado pelo Reduto de Caraguatá, onde o mesmo teria constatado "parecer ali ter mais fanatismo do que em Taquaruçu" (Diário da Tarde, 11/02/1914). Finaliza apontando as duas versões já indicadas por Queiroz (1977) sobre as tentativas de Correia Defreitas de estabelecer um acordo: primeiro a oferta de dinheiro e segundo a oferta de terras. Mas as duas ofertas tiveram respostas negativas, pois a condição para o restabelecimento da paz, da parte dos sertanejos, era o restabelecimento da monarquia, uma vez que a república representava os coronéis e a estrada de ferro, ou seja, a ordem espoliadora (Auras, 1984, p.88-89).

Paulo Ramos Derengoski (1986, p. 35) não trata da missão pacifista de Correia Defreitas, apenas o cita como indicação bibliográfica quando fala da posição do Tenente-coronel Aleluia Pires perante o ataque aos sertanejos. Para Aleluia Pires não cabia às forças legais combater os patrícios ignorantes que foram levados ao desespero por traficantes da província. Mas esse autor não fornece a indicação completa de onde Correia Defreitas teria feito o registro dessa posição do tenente-coronel. No seu trabalho de 2013, Derengoski (p.33-34) cita Correia Defreitas como deputado abolicionista, republicano exaltado, seguidor das ideias utópicas de Saint-Simon que partiu do Rio de Janeiro para a área da Lumber Corporation, mas foi recebido 
com hostilidade tanto pelos peludos como pelos pelados. Depois retoma a análise que já havia apontado em sua obra de 1986 sem acrescentar mais dados.

Renato Mocellin (1989) faz rápida referência a missão de Correia Defreitas. Comenta que antes do segundo ataque ao Reduto de Taquaruçu, o deputado progressista com ideias socialistas do Paraná, tentou convencer os sertanejos a se dispersarem, mas não obteve sucesso. Depois seguiu para Caraguatá com o mesmo intuito, mas mais uma vez a missão de Correia Defreitas fracassou. Já em sua última obra, Mocellin (2015, p.111) dedica uma seção para o deputado paranaense intitulada "UM DEPUTADO DO POVO", apontando que o deputado havia sido abolicionista, republicano histórico e possuía ideias progressistas apresentando projetos avançados para a época. A proposta de pacificação de Correia Defreitas não foi acatada pelos sertanejos de Taquaruçu porque estes queriam construir uma cidade independente de Curitibanos e edificar uma igreja em memória de São João Maria. Os de Caraguatá por sua vez disseram que não havia razão para se dispersarem pois não tinham a intenção de atacar ninguém. $\mathrm{O}$ autor aponta que não tem como ter certeza se o deputado do Paraná ofereceu dinheiro e terras para pôr fim ao movimento, mas que a única coisa certa é que os sertanejos não acreditavam nas promessas do governo e queriam acabar com o domínio dos coronéis.

Euclides Felippe (1995) fez uma coletânea de narrativas das tradições e crenças populares envolvendo o Contestado. Dentre as diferentes histórias aparece a de Correia Defreitas e sua ida à cidade santa de Taquaruçu para tentar uma solução pacífica, mas nada conseguiu devido a ausência da "gente de Eusébio" (p. 141), os homens capazes de decidir haviam se dirigido para Caraguatá e para lá também seguiu na "esperança de que alcançaria uma pacificação geral, antes do projetado ataque das forças do governo" (p. 152). Depois de três dias de viagem chegou em Caraguatá, no dia 9 de fevereiro, um dia após o massacre de Taquaruçu. Enquanto se esforçava para cumprir sua missão chegou a notícia do ataque à Taquaruçu e agora os sertanejos só pensavam em vingança. 0 chefe do Reduto de Caraguatá, Elias de Morais, por fim propôs o impossível ao deputado paranaense: não queriam terras, escolas, estradas e dinheiro que ele estava propondo, mas queriam que o governo devolvesse as vidas dos que haviam perecido em Taquaruçu. Certificando-se do fracasso dos seus esforços, Correia Defreitas deixa a região. 0 autor aponta que o próprio oficial Aleluia Pires não estava convencido de que no ataque ao reduto de Taquaruçu iria combater inimigos, mas sim arrasar, levar à morte os "pacatos e inofensivos sertanejos". Seu plano era permanecer com as tropas acampadas nas 
cercanias de Taquaruçu até conseguir a dispersão pacífica dos sertanejos, ou cerca-los e reduzilos pela fome.

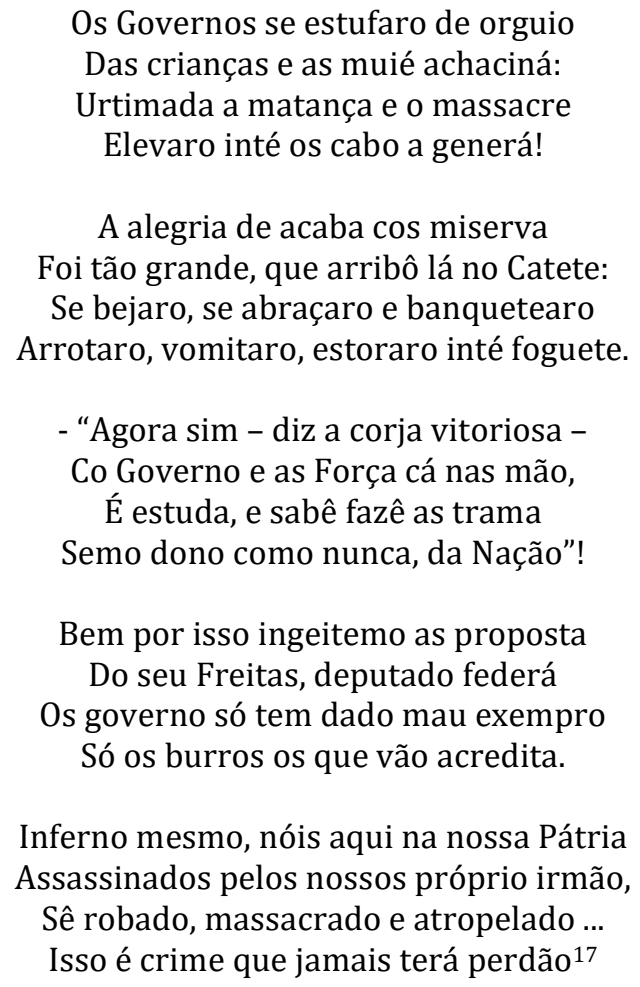

Nilson Thomé (1999) trata das diversas missões de paz enviadas para tratar com os sertanejos e entre elas está a do deputado Correia Defreitas que foi programada pelo jornal Diário da Tarde através de uma campanha humanitária. Para o autor, sensíveis com o que ocorrera em Irani em outubro de 1912 e receosos do que poderia via a ocorrer em Taquaruçu, foi enviada a comitiva liderada pelo deputado paranaense e composta pelo representante do jornal, o fazendeiro Antonio da Rocha Tico e pelos guias locais Antonio Cordeiro de Sampaio, Generoso Ribeiro e Firmino Mello (os guias tinham parentes no reduto de Taquaruçu e queriam tirá-los de lá). A missão foi bem recebida na cidade-santa de Taquaruçu e permaneceu lá por dois dias, mas não logrou êxito. Na tarde do dia 8 de fevereiro de 1912 começou o bombardeio que prosseguiu de forma ininterrupta pela noite chuvosa até a manhã do dia seguinte. "Os militares destroçaram Taquaruçu, liquidaram todos os que ali estavam e queimaram as casas" (THOMÉ, 1999, p. 183).

17 FELIPPE, 1995, p. 157. 
Élio Serpa (1999) destaca que o governo através do envio de representantes tentou fazer os sertanejos abandonarem a luta. Entre esses enviados estava Correia Defreitas, que como os outros, não logrou êxito mas forneceu importantes informações às tropas legais sobre os sertanejos para possíveis ataques.

Aujor Ávila da Luz (1999) aponta o envio de Correia Defreitas como emissário para dispersar os sertanejos pois o governo empregaria metralhadoras para atacar o reduto. Os sertanejos responderam que queriam muito conhecer uma metralhadora e que estavam esperando o novo ataque das tropas legais. 0 deputado do Paraná "num nobre esforço de pacificação e num nobre espírito de humanidade" (LUZ, 1999, p.190) segue para o reduto de Caraguatá na tentativa de negociar a paz. Desta vez, pediu a dispersão e em nome do governo ofereceu cem mil contos de réis. A resposta dos sertanejos foi que queriam um milhão de contos e a restauração da monarquia.

Paulo Pinheiro Machado $(2001 ; 2004)$ também faz menção a tentativa de Correia Defreitas de mediar "uma negociação antes do segundo e derradeiro ataque à Taquaruçu" (MACHADO, 2001, p. 220). O comandante Aleluia Pires permitiu essa visita de paz, pois segundo Machado (2004, p. 221) os militares estavam com hesitação para atacar o reduto por não verem "os sertanejos como inimigos, mas o viam sendo usados pelos políticos locais, os coronéis da Guarda Nacional, que por conta de sua politicagem, tinham provocado a reunião dos sertanejos".

Marilene Weinhardt (2002) traz uma nova proposta de análise da Guerra do Contestado. Ela estuda as representações do conflito através das narrativas vinculadas por quatro textos ficcionais sobre o conflito e dedica um capítulo ao texto jornalístico, no caso do Diário da Tarde, jornal de Curitiba que em 1914 empreendeu uma campanha pelo encaminhamento de soluções não armadas ao conflito. A autora analisa o processo de construção dessa campanha de pacificação, que tinha o slogan "PELA HUMANIDADE" como formadora de opinião. Destaca a intenção de colocar em evidência a rudeza dos sertanejos e a denominação "fanáticos" utilizada recebe o adjetivo de religiosos - "fanáticos religiosos", definindo esse termo. Os artigos do jornal se alteram entre aqueles que apontavam uma proximidade de paz e os outros que constatam que as chances do fim da revolta sem violência eram remotas. Nesse último caso temos o relato da ineficácia das tentativas de pacificação do deputado Correia Defreitas. 0 discurso humanitário do Diário da Tarde continua nos dias subsequentes ao ataque ao Reduto de Taquaruçu, mesclando as informações de várias fontes. Em 20 de fevereiro o jornal substitui o slogan "Pela Humanidade!" por "Novo Rumo" o qual agora pregava a incorporação 
dos sertanejos à sociedade nacional por meio da instrução. Mas ainda não havia ocorrido o Combate de Caraguatá que coloca abaixo essa esperança de "um novo rumo".18

Delmir José Valentini (2003, p. 91 e p.109) fala da missão pacifista de Correia Defreitas mas citando Queiroz (1977), não acrescenta nenhum dado novo.

Walmor Marcellino (2005) aponta o fracasso da missão do deputado Correia Defreitas aos redutos de Taquaruçu e Caraguatá ao tentar a conciliação dos insurretos oferecendo dinheiro, mas em resposta queriam a restauração da monarquia e as vidas das mulheres e crianças que haviam sido chacinadas em Taquaruçu. Sem acordo, as tropas oficiais se reorganizaram e iniciaram a marcha sobre os revoltosos.

Auro Sanford de Vasconcellos (2008) em seu romance histórico decide narrar a saga de Francisca Roberta, a Chica Pelega, a legendária heroína da insurreição destacando o protagonismo feminino na Guerra do Contestado. No capítulo XXIV o autor trata do massacre de Taquaruçu e cita a visita de Correia Defreitas no reduto buscando uma solução pacífica para o conflito. Acordou com o chefe militar que iria pessoalmente procurar os líderes sertanejos no interior do reduto antes de acontecer o ataque armado. Pede encarecidamente que o ataque não ocorresse antes de seu retorno pois acreditava ser capaz de contornar a situação. Em seguida Vasconcellos (2008, p. 187) dedica um parágrafo para apontamentos de alguns dados biográficos do deputado Correia Defreitas o apontando como abolicionista, idealista de "ideias avançadas" que eram verificadas em seus projetos de lei apresentados na Câmara dos Deputados, tais como distribuição de terras, seguro operário, pensão por invalidez ou velhice, não conseguindo aprovar nenhum. Quando Correia Defreitas chega em Taquaruçu encontra o reduto esvaziado, somente com mulheres, crianças, inválidos e idosos. Os líderes haviam seguido para Caraguatá. 0 parlamentar decide seguir para Caraguatá, mas sua "cansativa missão de boa vontade" foi em vão pois enquanto retorna desse último reduto, Taquaruçu foi violentamente atacado.

Tarcisio Carvalho (2009) apresenta a Guerra do Contestado como uma luta de classes não apenas no aspecto de violência física, mas no sentido da disputa entre os valores e as representações que estavam em jogo. Apresenta como a classe dominante interpretou o contexto dessa guerra e os discursos construídos sobre os caboclos pela imprensa, pelo exército e pelos membros dessa classe que ocupavam postos políticos. 0 destaque é dado aos discursos

180 jornal Diário da Tarde demonstrou um compromisso humanitário antes de aderir a voz oficial. 0 jornal Commercio do Paraná sempre vestiu a camisa governista e isso pode ser percebido pelos termos utilizados nos artigos como, por exemplo, o termo jagunço para se referir aos sertanejos. (WEINHARDT, 2002, p. 68) 
construídos pelo estado republicano que produziam e reproduziam valores ideológicos para justificar e legitimar sua intervenção armada sobre os sertanejos. No trabalho de Carvalho (2009), Correia Defreitas aparece na seção em que o discurso da imprensa é analisado. 0 principal aspecto desse discurso é consolidar a ignorância e o analfabetismo como os principais atributos do sertanejo, o que explicava o atraso na agricultura e a facilidade com que eram tomados pelas superstições e falsos profetas como os monges. "Os elementos modernos $e$ civilizados (escola, fábrica, higiene e cultura intensiva) são completamente desconhecidos do caboclo que, na grande maioria das vezes apela para algum curandeiro, profeta ou monge (CARVALHO, 2009, p. 187). O documento de análise de Carvalho (2009) que faz referência ao Correia Defreitas é um excerto de Antonio Hercilio ${ }^{19}$ publicado na Revista Casa do Lavrador da Secretaria de Agricultura do Paraná. ${ }^{20}$ Hercilio (1912) elogia a intenção do deputado paranaense de combater o analfabetismo e cita a fala de Correia Defreitas na Câmara dos Deputados do dia 24 de outubro de 1912 com relação ao Combate do Irani:

É por causa de factos d'essa ordem que tenho apresentado projectos de combate ao analfabetismo, uma das mais fundas e dolorosas chagas que afligem a nossa sociedade. Infelizmente, o Congresso não tem tomado em consideração esse problema, que é capital, e essencial para que possamos constituir uma nação forte, de homens civilizados (HERCILIO, 1912, p. 172, grifo do autor).

Na página seguinte Hercilio (1912, p. 173) cita mais uma vez Correia Defreitas quando faz menção à figura do coronel João Gualberto, morto no Combate do Irani. Segundo o autor, o deputado havia dito em seu discurso que João Gualberto era "o ídolo de todas as classes d'esta terra", ou seja, um herói. Hercilio (1912) complementa seu pensamento reforçando a imagem do caboclo como bandido selvagem que matou o coronel "trespassado pelo facão do caboclo facínora."

Liz Dalfré (2014, p.90) ao analisar o movimento do Contestado no Diário da Tarde cita Correia Defreitas como um importante político paranaense que visitou os redutos da região contestada tentando apaziguar os sertanejos, tentando os convencer de se dispersarem, oferecendo em troca garantias de vida e assentamento.

\footnotetext{
${ }^{19}$ Embora seja um texto assinado por Antonio Hercilio e a localidade indicada seja Antonina, ano de 1912 não conseguimos localizar mais dados sobre o autor do excerto.
}

${ }^{20}$ HERCILIO, Antonio (1912). Excertos de um escrito inédito (continuação). IN: Almanaque da Revista A Casa do Lavrador da Secretaria de Agricultura, Indústria e Commercio para 1913. Anno I. Curitiba: Typographia da Penitenciaria, p. 170-174. 
Karina Woitowicz (2014) faz a análise discursiva do jornal paranaense Diário da Tarde durante os anos de 1912 a 1916. Por meio da análise de discurso a autora identifica as vozes e posicionamentos tomados pelo periódico durante o período da Guerra do Contestado, reconhecendo um trabalho simbólico cotidianamente desenvolvido pela imprensa, em seu processo de construção do real e em seu "dizer" jornalístico. Assim, a autora analisa a campanha "Pela Humanidade!" que contou com o respaldo de autoridades e grupos da capital paranaense 21 que se apresentaram como aliados dos sertanejos, em nome de sentimentos patrióticos, junto à opinião pública. Essa campanha aderia a um fim pacífico para o movimento já que as operações legais negavam essa intenção, conforme Diário da Tarde de 11 de fevereiro de 1914:

Comemorou-se o assalto a Taquarussu. Os caboclos foram feridos a bala, estraçalhados a metralha, espedaçados a canha. Homens, mulheres e crianças morderam o pó, com os membros decepados, o peito varado, o crânio fulminado, o ventre estirpado. 0 sangue tingiu de rubro as matas do sertão catarinense.

A campanha de opinião pública "Pela humanidade!" tinha o objetivo de sensibilizar a população e apontar os rumos para uma solução "sem derramamento de sangue". Esses eram os principais elementos presentes nos discursos do jornal que publica as correspondências enviadas pelo deputado paranaense Correia Defreitas que procurava apagar as marcas de violência comumente atribuídas aos sertanejos e o perfil de criminoso. 0 sertanejo não era mais falado como uma ameaça à sociedade, mas como parte e principalmente vítima dela. Esta campanha de pacificação que enviou pacificadores ${ }^{22}$, homens que se expuseram a todos os perigos e à própria morte em bem da humanidade, representou um elemento significativo na definição dos rumos do Contestado. Para a autora, houve uma "migração de sentidos" que vão do perfil de criminoso ao de vítima, a partir de mecanismos e estratégias discursivas que procuraram traduzir e significar as origens e a situação dos sertanejos e dos integrantes do movimento para se produzir sentido sobre os fatos. Os sertanejos foram vistos dentro de um quadro de referências próprias e os textos procuravam apagar as marcas de violência atribuídas a eles:

210 jornal Diário da Tarde teve seu primeiro número publicado em 18 de março de 1899. Foi fundado por Estácio Correia. Na época da campanha “Pela Humanidade!” seu diretor era Jayme Ballão.

22 O deputado Manoel Correia Defreitas, o emissário do jornal Diário da Tarde Antonio da Rocha Tico e os guias Antonio Sampaio, Generoso Ribeiro e Firmo de Mello (WOITOWICZ, 2014, p. 115). 
Os fanáticos não praticaram uma agressão ainda, um roubo, uma depredação. Vão ao extremo de queimar dinheiro, viveres e munições apreendidas para não se aproveitar do que é alheio ${ }^{23}$. A própria lenda da existência de perigosíssimos e facínoras bandidos entre os fanáticos é desfeita por inteira. Agora que o exército já se defrontou plenamente na resistência oposta à coluna Adalberto, ponha-se um paradeiro aos mais violentos meios empregados para dispersar os caboclos. Usa-se de outros meios, o sítio, por exemplo, já que a intervenção pacificadora dos emissários do Diário da Tarde não surtiu o almejado efeito... (Manoel Correia Defreitas, Diário da Tarde de 14 de fevereiro de 1914).

Os discursos veiculados pela imprensa contribuíram para consolidar a imagem do sertanejo como um mestiço inferior, através de suas características de fanático, selvagem, bárbaro, inculto, desamparado, analfabeto, bandido e criminoso; a imagem dos militares como guerreiros e a imagem dos grandes proprietários de terras como vítimas do conflito social que envolveu o homem do campo. Woitowicz (2014) conclui que a campanha "Pela Humanidade!” da qual Correia Defreitas participou permitiu a compreensão da condição sertaneja durante a Guerra do Contestado quebrando as marcas de um pensamento hegemônico marcado pelo argumento racial que buscava definir o perfil do sertanejo por meio de suas descrições físicas e morais, vinculando suas atitudes ao crime e intensificando o descrédito de sua religiosidade. 0 vínculo do sertanejo ao analfabetismo, à ignorância e ao fanatismo é parte integrante, é o consenso presente no discurso simbólico construído ao longo do conflito demonstrando o potencial de ação e representação que configurou a atividade da imprensa durante esse processo. Em suma, o jornal cria e recria consensos que a cada repetição necessitam menos de explicações.

O Instituto Histórico e Geográfico do Paraná (IHGPR) fornece a visão oficial do Paraná sobre a Guerra do Contestado através de três obras publicadas na coleção Estante Paranista ${ }^{24}$. A primeira obra é de Alcibíades Miranda (2012) que se enquadra no grupo de obras escritas por militares $^{25}$, cuja primeira edição foi publicada em 1987, mas a redação é do ano de 1938. A obra

\footnotetext{
${ }^{23}$ Para entender o sistema de reciprocidade praticado entre os sertanejos consultar Margarido (1974).

24 Conforme comunicação de Luiz Carlos da Silva "Reafirmando velhas certezas: O IHGEP nos 70 anos do Movimento do Contestado (1986)" realizada no III Simpósio do Centenário do Contestado - FAFI/UNESPAR de 4 a 6 de novembro, União da Vitória/PR.

25 Entre outras obras escritas por militares destacamos:

ASSUNÇÃO, Herculano T. de. A Campanha do Contestado. 2 volumes. Belo Horizonte: Imprensa Oficial do Estado, 1917 e 1918.

CERQUEIRA, Antonio Alves. A jornada de Taquaruçu: feito guerreiro. Rio de Janeiro: [s.n], 1919
} 
está dividida em três partes: 1- As causas da luta; 2 - A luta e 3 - Pacificação ${ }^{26}$. Na segunda parte ele trata das oito expedições militares que foram enviadas para a região do Contestado entre fins de 1912 a princípios de 1915 contra os “jagunços fanáticos” e ressalta que somente a última fora bem-sucedida. Manoel Correia Defreitas aparece no texto na descrição da Quinta Expedição que foi organizada após o insucesso do ataque militar ao reduto de Taquaruçu em dezembro de 1913. Essa expedição atacou o reduto de Taquaruçu "apenas" no dia 8 de fevereiro de 1914, pois o comandante Aleluia Pires aguardava "o resultado da viagem pacificadora do deputado paranaense Correia Defreitas ao acampamento de Taquaruçu, com assentimento das autoridades estaduais" (MIRANDA, 2012, p. 69). Nutria o comandante Aleluia Pires a esperança de que os "fanáticos" se dispersassem à aproximação das forças legais, confiando ainda no resultado dos emissários pacificadores que haviam ido ao acampamento deles em missão humanitária. Além de Correia Defreitas, Miranda (2012) destaca outros emissários pacificadores como o Frei Rogério Neuhaus (que chegou a ser agredido pelos "fanáticos") e o padre José Lechner, que assim como o deputado paranaense, não alcançaram êxito nas negociações. 0 discurso de Miranda é de que o exército agiu com civilidade e racionalidade enviando emissários para tratarem com os sertanejos sua rendição; e de que os "fanáticos" como sempre reagiram com violência desmedida. 0 autor esquece que o exército também utilizou de violência desmedida o que indica que precisamos inverter essa lógica de análise.

PEIXOTO, Dermeval. [pseudônimo Crivelaro Marcial]. Campanha do Contestado: episódios e impressões. 3 volumes. Rio de Janeiro: Edição do autor, 1916

SOARES, José O. Pinto. Apontamentos para a história: o Contestado. Porto Alegre: Oficinas gráficas da Escola de Engenharia de Porto Alegre,1920.

SOARES, José O. Pinto. Guerra em Sertões Brasileiros. RJ: Papelaria Velho, 1931.

O relatório do General Setembrino de Carvalho é um texto que se reveste de observações e comentários de caráter político-social que permitem considerá-lo fora da classificação de documento meramente burocrático e ser enquadrado como uma obra clássica escrita por um militar.

Carvalho, Fernando Setembrino de. Relatório apresentado ao general José Caetano de Faria, Ministro da Guerra, pelo comandante das forças em operações na Guerra do Contestado. Rio de Janeiro: Imprensa Militar, 1915.

Apesar de todos serem oficiais do Exército Brasileiro e não possuírem o mínimo conhecimento ou domínio sobre a ciência da História, seus trabalhos servem como fontes importantes, principalmente para a compreensão do pensamento militar sobre a Guerra do Contestado. Para saber mais sobre a produção militar sobre o Contestado ver RODRIGUES, Rogério Rosa (2008). Veredas de um grande sertão: a Guerra do Contestado e a modernização do Exército. Rio de Janeiro: Doutorado em História da UFRJ.

${ }^{26}$ Alcibiades Miranda não era paranaense, então, no prefácio da primeira edição o presidente do IHGPR alerta que talvez ele aborde questões de maneira que não "agrade aos paranaenses". Miranda critica negativamente personalidades paranaenses como José Cleto da Silva e Manoel Alencar Guimarães e revela-se a favor da emancipação da região contestada criando-se um novo território. Depois, deveria ser realizado um plebiscito que iria determinar a anexação desse território a um dos estados. 
A segunda obra é de Fredericindo Marés de Souza (1987) que aborda a gestão do presidente do estado do Paraná Carlos Cavalcanti e a Guerra do Contestado ${ }^{27}$. Marés de Souza (1987, p.187-203) fala da Campanha do Diário da Tarde "Pela pacificação e pela humanidade!" dirigida pelo jornalista e deputado Jayme Ballão ${ }^{28}$ no sentido de evitar o emprego das tropas legais contra os sertanejos. 0 jornal defendia que era preciso escutar os motivos da revolta sertaneja e que todos tinham o direito de professar a sua fé (Diário da Tarde, 10/01/1914). A campanha "PELA HUMANIDADE!" teve intensa repercussão e adesão, inclusive de Vidal Ramos (presidente do estado de Santa Catarina) e Carlos Cavalcanti (presidente do estado do Paraná). No entanto, o autor aponta que nem os governos locais e nem o central enviaram aos redutos, parlamentares com amparo legítimo para resolver a situação ${ }^{29}$ : Carlos Cavalcanti alegava que a área estava fora de sua administração, Vidal Ramos alegava que as tropas legais estavam lá para resolver a questão e o general Alberto de Abreu ${ }^{30}$ cumpria as ordens do presidente da república

27 Outra publicação de Fredericindo Marés de Souza é o texto ficcional que foi escrito sobre o Contestado intitulado “Eles não acreditavam na morte: romance dos tempos dos fanáticos do Contestado", publicado em 1978 pelo Instituto Histórico e Geográfico do Paraná. Essa obra, apesar de suas limitações do ponto de vista estético, revela as particularidades no estabelecimento do diálogo do discurso histórico com o ficcional.

Com relação a obra da Estante Paranista № 29 - Marés de Souza (1987) - o autor analisa a carreira militar de Carlos Cavalcanti, mas não problematiza o que ele fez na sua gestão como presidente do Paraná. Marés de Souza não coloca no seu texto a crítica que o secretário de obras públicas e colonização do Paraná do governo Carlos Cavalcanti, José Niepce da Silva (1876 - 1935), fez a Affonso Camargo, então o $1^{\text {o }}$ vice-presidente de Estado e ao mesmo tempo advogado do Grupo Farquar (Estrada de Ferro São Paulo - Rio Grande e a Southern Brazil Lumber \& Colonization Company). Ressaltamos que o autor fez um grande levantamento nos periódicos da época, portanto ele teve acesso aos seis textos de Niepce da Silva criticando Affonso Camargo que foram publicados no jornal A Tribuna, a partir de 11 de fevereiro de 1914 sob o título "Desmascarando os hipócritas”, porém não faz menção a eles em seu trabalho.

28 Jayme Ballão (1869-1930) filho de José de Sá Ballão e de Carolina Schleder Ballão. Foi professor, escritor, industrial, advogado, jornalista e político. Destacou-se no jornalismo paranaense como editor e fundador de periódicos. Ainda na juventude criou a revista "Vida Literária", além de ter sido diretor da "Gazeta Paranaense". Durante os anos da Revolução Federalista, desenvolveu um jornalismo combativo e nesta atitude contraiu desafetos dentro do governo. Por esta razão, sofreu perseguição e foi preso. Ao ser julgado, foi absolvido das acusações impostas. Em 1903 fundou o Diário do Comércio e anos depois comprou o Diário da Tarde. Na política, exerceu os cargos de Camarista municipal e Deputado estadual durante a década de 1910. Entre as diversas atividades que atuou durante a sua vida, Jayme Ballão teve especial dedicação às letras, em uma relação diferente das matérias e crônicas do jornalismo. Em parceria com Augusto Stresser, ajudou a criar a primeira ópera paranaense como libretista de "Sidéria". A ópera estreou, com grande sucesso, em Curitiba, na sexta-feira, dia 3 de maio de 1912. Foi sócio fundador do Centro de Letras do Paraná e o seu presidente no ano de 1922. Exercia o cargo de oficial do Registro de Títulos de Curitiba quando faleceu, aos 61 anos (MENDONÇA, 1992). Disponível também em http://www.alep.pr.gov.br/deputados/perfil/278-jayme-ballao. Acesso em 12.novembro.2016.

29 Houveram alguns emissários enviados aos redutos na tentativa de dispersarem os sertanejos para evitar o massacre: Frei Rogério Neuhaus, os espiões Periquito e Valeriano, o benzedeiro Damaso Padilha, mas nenhum tinha o poder de decidir com legitimidade (A Tribuna, 16/02/1914). Ver Cronograma Missões Pacifistas anexo.

${ }^{30}$ Alberto Ferreira de Abreu, inspetor da 11aㅡ Região Militar, Paraná desde a sua criação em junho de 1913 até 24 de agosto de 1914 (A República de 11/06/1913 e de 26.08.1914). Nasceu em Paranaguá no dia 11 de junho de 1853, filho de Antônio Cândido Ferreira de Abreu e de Maria Cândida Guimarães Ferreira de Abreu. Era casado com Maria Lins Ferreira de Abreu. Seu avô materno era o visconde de Nacar. Seu irmão, Cândido Ferreira de Abreu, foi 
para intervir militarmente recomendando o tratamento humano, mas ao mesmo tempo aprovando o plano de Aleluia-Lebon Regis de ataque ao reduto (Commercio do Paraná, 23/01/1914). 0 jornal Diário da Tarde passa da doutrinação à ação e enviou um mensageiro de paz - o coronel Antonio Maria Rocha Tico que durante uma das viagens realizadas ao local encontra o deputado do Paraná Manoel Correia Defreitas, que era da oposição e tinha o objetivo de evitar o massacre dos sertanejos. Correia Defreitas se valeu de seu nome e de sua ótima capacidade de oratória para essa missão, segundo Marés de Souza. 0 autor destaca a boa recepção que Correia Defreitas e comitiva tiveram no Reduto de Taquaruçu. Daí passa a descrever as impressões do deputado sobre o local: a constatação do "fanatismo religioso", a organização das lideranças, o número de pessoas, a escassez de armamento, etc. Para Correia Defreitas os sertanejos não eram malfeitores para serem tratados à bala, apenas reclamavam das perseguições seguidas. Marés de Souza (1987, p.199) destaca que Correia Defreitas, o “deputado pacificador" tentou "com sua eloquência tribunícia convencer os sertanejos a se dispersarem, pois de modo contrário, seriam implacavelmente sacrificados". A missão fracassou. Os sertanejos prometeram aceitar os conselhos do deputado paranaense se os chefes de Caraguatá (Elias de Moraes) e Perdizinhas concordassem (Diário da Tarde, 06/03/1914).

Correia Defreitas parte com Generoso Sampaio e Firmino de Mello rumo ao Reduto de Caraguatá em busca de entendimento com os chefes do movimento. Nesse reduto o deputado do Paraná constada que o povo estava mais fanatizado e desconfiado (Diário da Tarde, 23/02/1914). Novamente fornece dados sobre o número de pessoas nos redutos de Caraguatá e Perdizinhas, do armamento e do ambiente hostil com que foram recebidos. Marés de Souza (1987, p.207-225) comenta da oferta de terras que Correia Defreitas teria feito aos sertanejos com o objetivo de obter a paz. Em entrevista ao jornal A Noite, de Porto Alegre, de 11/04/1914, ele relata que caso o governo de Santa Catarina perseguisse os sertanejos esses seriam conduzidos ao Paraná e lhe seriam concedidas terras como era feito com os colonos estrangeiros.

deputado federal (1903-1905) e senador (1906-1914) pelo estado do Paraná, além de prefeito de Curitiba. Cursou a Escola Militar do Rio de Janeiro, diplomando-se engenheiro militar e bacharel em matemática e ciências físicas. Sua trajetória profissional esteve quase toda ligada às atividades militares. Até reformar-se com a patente de marechal, chefiou as obras militares nas províncias do Paraná e de Santa Catarina, comandou os distritos militares paulista e paranaense, e foi diretor da Intendência de Guerra do Rio de Janeiro e do Arsenal de Guerra da Bahia. Além disso, foi diretor das estradas estratégicas do Paraná. Foi eleito deputado federal pelo Paraná para a legislatura 1915-1917. Não chegou a ser deputado estadual conforme aponta algumas narrativas biográficas. (Disponível em http://www.arvore.net.br/Paulistana/Moraes 3.htm. Acesso 06.nov.2016). Faleceu em 1933 (Commercio do Paraná de 30/03/1933). 
Mas a oferta não foi aceita. Queriam a restauração da monarquia, o objetivo da luta tinha passado ao cunho político.

E o republicano socialista, que era Correia Defreitas, vendo abalados os seus esforços, retirou-se às pressas, sem poder "evitar tanta sangueria inútil", através de carreiros obstruídos, serranias, matos fechados e passos crescidos pelas grandes chuvas. Nem ao menos comunicou ao comando militar de Caçador os resultados infrutíferos de suas mediações. No primeiro trem, tomado em uma das estações mais próximas, abalou-se para o Rio Grande do Sul. De lá reapareceu dando entrevistas reveladoras de seu espírito humanitário aos jornais. Na sua opinião, aliás demasiadamente otimista, e irreal, um cerco de oito dias liquidaria o conflito. (Diário da Tarde, 13/04/1914).

Marés de Souza (1987, p.231) finaliza sua referência ao deputado paranaense com as acusações que esse recebeu por sua missão pacifista. Alguns oficiais do exército sem saber ao que atribuir a reação dos sertanejos acusaram Correia Defreitas de "mascarado como mensageiro da paz" ser enviado aos redutos com o objetivo de ensinar-lhes técnicas de guerrilha. Essa insinuação teve origem quando o deputado do Paraná viu que sua missão de paz havia fracassado e decide aconselhar os sertanejos a não se conservarem aglomerados para evitar o massacre em massa, pois seriam derrotados (A Tribuna, 12/03/1914).

A terceira obra é a de Mario Marcondes de Albuquerque (1987). Publicada nos anos de 1980, procura romper com o silêncio que havia no Paraná sobre o Contestado e fazer críticas as políticas de recuperação da história da guerra realizadas pelo governador de Santa Catarina Espiridião Amin 31 . 0 presidente do IHGPR, Luiz Carlos Pereira Tourinho, na apresentação coloca que sempre ouviu falar da Guerra do Contestado como uma rebelião de caráter messiânico promovida por falsos monges, mas que havia surgido uma outra tese e que a Guerra do

310 silêncio por parte do governo durante décadas a respeito do Contestado seria quebrado por ações que buscariam não só enaltecer os sertanejos, ou caboclos, numa total mudança de postura, mas também estabelecer uma série de elementos que solidificassem uma memória dos acontecimentos, além de criar e manter legados ou patrimônios na forma de datas comemorativas, símbolos e locais de apresentação ou exposição do tema Contestado. As atenções dadas ao tema do Contestado pelo governo estadual catarinense, que procurava transformá-lo em símbolo patrimonial cultural, assumiriam uma dimensão maior a partir de 1982.0 candidato ao governo estadual, Esperidião Amin Helou Filho (PDS), utilizaria a imagem do Contestado como parte de sua campanha eleitoral em 1982, em que a "luta dos pequenos" (entre os quais estariam os sertanejos que combateram no Contestado) simbolizaria a força dos catarinenses na busca por justiça e pela defesa do território catarinense. Para além de uma apropriação pelo discurso eleitoral, ocorreu, após a eleição de Amin, todo um investimento no tema, que passou pela elaboração de estudos, publicações, vídeos, além da construção e implantação de marcos físicos (monumentos e placas) relacionados ao Contestado em lugares onde haviam se desenvolvido acontecimentos significativos para o evento, a exemplos de combates e a construção de redutos ou cidades santas (LAZARIN, 2004, p. 115). 
Contestado passou a ser vista como "uma rebelião de caráter social dos caboclos que habitavam a região contra os fazendeiros latifundiários e a pobreza generalizada" (ALBUQUERQUE, 1987, p.7).

Na seção "Hostilidades geradas pelo fanatismo", Albuquerque (1987, p. 66) faz uma rápida menção ao deputado Manoel Correia Defreitas que teria tentado "novamente se aproximar dos redutos e tratar do apaziguamento". Porém o autor não indica no texto como, onde e quando teria sido a outra tentativa de aproximação para entendermos esse "novamente" do excerto acima. Bem como não dá mais detalhes da última tentativa deixando essa menção solta no texto e de difícil compreensão.

A missão pacifista de Correia Defreitas ou sua posição perante a questão de limites também são relatados em vários trabalhos acadêmicos que ainda não foram publicados.

Naiara Ribeiro (2004) procura analisar a participação de Correia Defreitas no conflito relacionando fontes e bibliografia demonstrando que não há uma homogeneidade de discurso: as soluções violentas encontraram resistência. Destaca que o deputado paranaense passou de teórico do conflito para observador, o que o fez revisar suas interpretações anteriores que iam na linha do discurso hegemônico que invalidava qualquer ação popular que não estivesse dentro do padrão de ordem e civilidade pré-estabelecidos. Com a sua "ida à campo" pode compreender melhor a complexidade da situação, que se tratava de um problema crônico da estrutura social brasileira e que seria necessária modificar essa situação se o objetivo era construir uma socieda demais democrática, conforme pregava o deputado em seus discursos. Porém, a autora levanta uma outra perspectiva de análise sobre a missão pacifista de Correia Defreitas que teria sido apontada por Antonio Tota (1983). Para esse autor o deputado paranaense seria um representante das oligarquias cafeeiras de São Paulo e do Rio de Janeiro e que se dirigiu até a área de conflito com o intuito de defender os interesses desses grupos em relação à consolidação da república. A autora conclui que Tota não aprofunda a questão, o que não permite a verificação dessa sua hipótese e nem quais fontes utilizou em suas pesquisas para chegar à essa conclusão. Analisando a referência de Tota indicada pela autora, concluímos que ela deva ter se confundido, pois a obra de Tota de 1983 não chega nem a citar Manoel Correia Defreitas e nem faz menção à missão pacifista por ele comandada. Não conseguimos localizar nenhuma outra obra de Tota que tratasse sobre a Guerra do Contestado.

Amélia Siegel Corrêa (2006) retoma as narrativas biográficas que existiam sobre Manoel Correia Defreitas e apesar da importância da questão de limites entre os estados do 
Paraná e de Santa Catarina e da Guerra do Contestado em sua trajetória, pois por anos ele se expressava sobre o assunto, a autora apenas se limita a indicar que "não conseguindo solucionar a questão por instâncias judiciárias, interviu pessoalmente no assunto, buscando solucioná-las mediante contato direto com os sertanejos no sertão catarinense" (CORRÊA, 2006, p. 110).

Bruna Scheifer (2008, p. 103-104) aponta que durante a Guerra do Contestado várias foram as obras públicas paralisadas no estado do Paraná devido à crise financeira enfrentada. Artigo publicado no Diario do Commercio de $1^{\text {o }}$ de julho de 1917 descrevia a Guerra do Contestado "como um sorvedouro de dinheiro e de vidas no Paraná". Em Paranaguá houve resistência em aceitar o parecer do presidente da República favorável à Santa Catarina, através do qual o Paraná perdia boa parte de suas terras. Correia Defreitas, identificado pela autora como um comerciante local ${ }^{32}$, entre outros parnanguaras, levantou voz contra a decisão, "protestou garantindo que o acordo não se cumpriria a não ser depois que os paranaenses empunhando armas, defendessem seus direitos", mas segundo o jornal "era inútil discutir diante da decisão do presidente da república. Se ele falou e o governo do estado acatou, então está acabado!" (Diário do Commercio, 07/07/1917). Por conta disso, o presidente Venceslau Brás mandou um navio para ficar ancorado no Porto de Paranaguá até que os ânimos se acalmassem.

\footnotetext{
${ }^{32}$ Nessa época Manoel Correia Defreitas não era mais deputado federal pelo Paraná.
} 


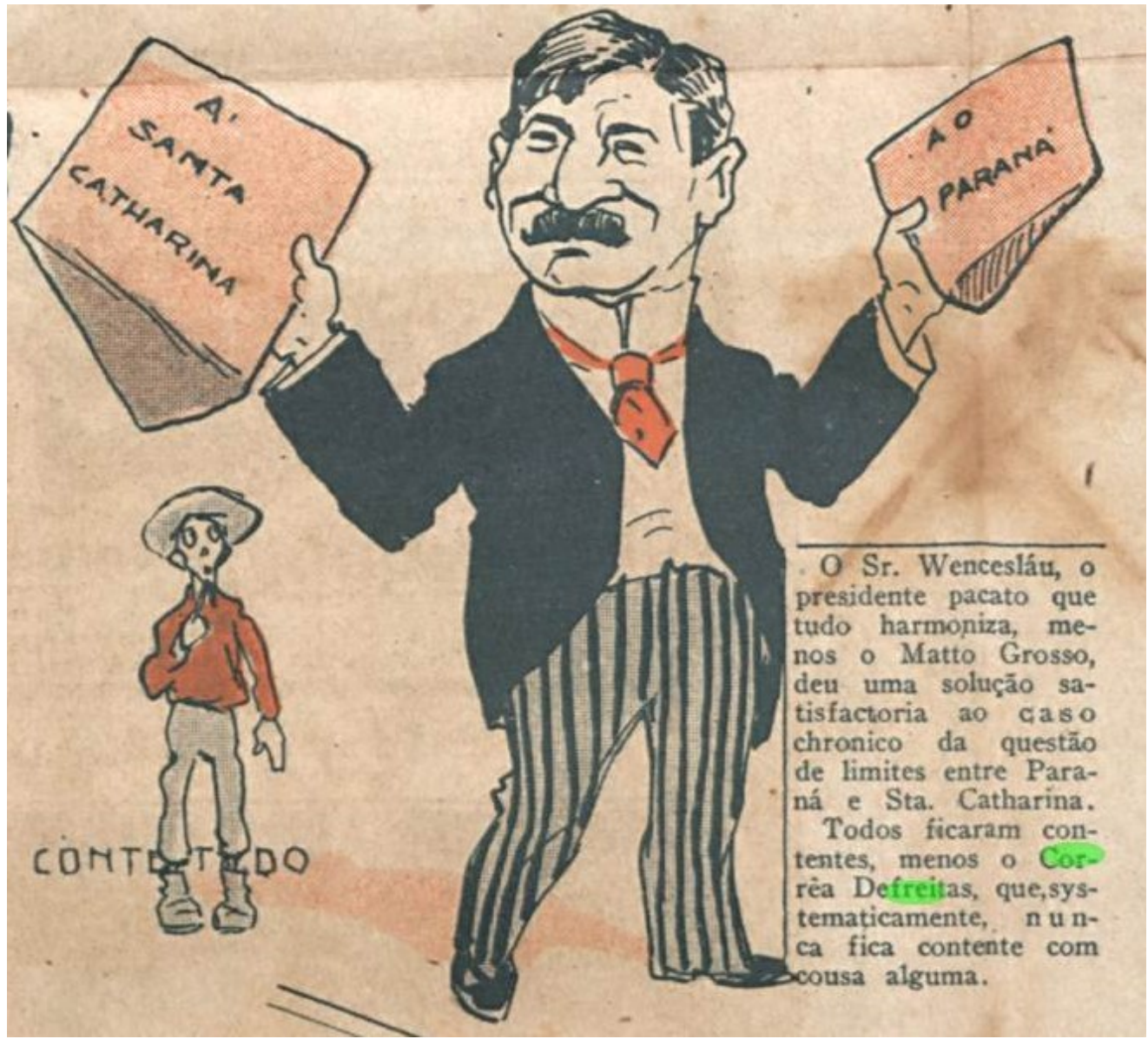

A charge retrata a figura do presidente da república Wenceslau Brás com a divisão do território contestado em mãos (repare que na mão esquerda, a parte referente à Santa Catarina é maior que a parte referente ao Paraná na mão direita). 0 presidente é observado pelo Zé do Povo, cuja expressão facial é de quem está entendo pouco da situação.

Nos dizeres, o periódico ainda faz menção ao caso de limites entre os estados do Mato Grosso e do Amazonas ${ }^{33}$ que apesar do acórdão de 1889 ainda não estava com a situação de limites resolvida. Finaliza destacando o papel questionador de Correia Defreitas que o deixou conhecido como alguém que nunca estava satisfeito com as decisões oficiais.

Fonte: 0 Malho, 7 de outubro de 1916.

Eduardo Salomão (2012) estuda a devoção ao mártir católico São Sebastião no

Contestado e a relação desta prática religiosa com a crença no retorno do rei Encoberto D.

Sebastião, desaparecido na batalha de Alcácer Quibir, em 1578. Para o autor, mediante um processo de reelaboração dos símbolos e significados da religiosidade, no Contestado o mártir católico é quem entrara em cena no comando de um Exército e não mais o rei Encoberto. No

\footnotetext{
33 O Supremo Tribunal Federal em 11.11.1889 fez um acordão entre o Amazonas e Mato Grosso: ordenou que o estado do Amazonas restituísse o território de Mato Grosso e estabeleceu os limites entre esses dois estados. Numa das sessões da Câmara, Correia Defreitas fala da questão dos limites entre os estados do Paraná e de Santa Catarina e se remete ao papel de Supremo Tribunal que invadiu as atribuições do Poder Legislativo na questão idêntica ocorrida entre o Mato Grosso e o Amazonas e questiona se seria tomada a mesma atitude no caso entre PR e SC (Correio do Estado, 09.10.1910).
} 
capítulo "A Guerra de São Sebastião" o autor cita Manoel Correia Defreitas e sua missão pacificadora baseado na obra de Queiroz (1977). As forças militares estavam de prontidão para atacar a cidade santa de Taquaruçu. A única solução rápida para evitar o confronto era convencer Eusébio, o líder dos sertanejos, a desfazer o acampamento. Várias pessoas se encarregaram de negociar com os devotos, entre elas o Frei Rogério Neuhaus e o deputado federal paranaense Manoel Correia de Freitas.

Antes que se concretizasse a ação militar contra a cidade santa, acompanhado do Coronel Antonio da Rocha Tico, fazendeiro paranaense e correspondente do jornal curitibano Diário da Tarde, o deputado Correia Defreitas empenhou-se em alcançar uma solução pacífica para a questão. Munido de uma carta do militar e político catarinense Lebon Regis, solicitou ao comandante Aleluia Pires que aguardasse o resultado das negociações antes de cumprir as ordens do General Abreu. As conversações duraram dois dias, gastos de barraco em barraco na tentativa de convencer os chefes do movimento de que o melhor era abandonar a cidadela e dispersar o povo. Os relatos provenientes das negociações de Correia Defreitas informam que, após o primeiro ataque, em dezembro de 1913, à frente do movimento encontravam-se o "preto" Antônio Linhares e seu filho de 10 anos de idade, exercendo os papéis outrora reservados a Eusébio e Joaquim. Anacleto Ribeiro era o "comandante dos Pares". A cidade santa era formada de aproximadamente 200 casas, abrigando 600 mulheres e crianças e 200 homens. A comunidade se reunia duas vezes ao dia ao toque de tambor, e enfileirados percorriam o povoado dando vivas aos santos. Os argumentos de Correia Defreitas não convenceram os devotos, que enfatizaram estar reunidos em santa missão sem intenções belicosas. Meses depois de concluída a missão do deputado, o ex-integrante do movimento José Froglis declarou que os chefes "disseram que tudo que ele [Correia de Freitas] dizia era muito bom, mas para nada servia, porque tinha chegado a hora da guerra Santa de São Sebastião e da monarquia" (Diário da Tarde, 07.04.1914) $)^{34}$.

Outra fonte de pesquisa sobre a missão pacifista de Correia Defreitas são os diferentes sítios e blogues disponíveis nas redes sociais. Todos têm como base a obra de Maurício de Queiroz (1977), porém alguns apontam observações mais atuais sobre a Guerra do Contestado. Ernani Gennari (2007) aponta a hesitação de alguns oficiais militares que não viam os sertanejos

34 Consultar também BRASIL. Congresso Nacional. Anais da Câmara dos Deputados, sessão de 30 de dezembro de 1914. Vol. XIV. Rio de Janeiro: Imprensa Nacional, 1916, p. 583. 
como inimigos, mas sim como vítimas da politicagem das autoridades. Diante desta situação, o comandante Aleluia Pires consente que o deputado federal paranaense, Manoel Correia Defreitas, fizesse uma tentativa pacífica de convencer os moradores do reduto a se dispersarem.

Do relato publicado no Jornal da Tarde, de Curitiba, em 6 de março de 1914, lemos:

Em Taquaruçu há poucas armas. Todos, entretanto, andam armados com "cacetes de três gumes". Apesar de tão reduzido armamento, asseguram que se baterão contra qualquer força que vá atacá-los, pois há um profundo ressentimento político e social. Queixam-se das autoridades de Curitibanos e Campos Novos, dizendo que se estes não os perseguissem, iriam imediatamente "pra casa tratar de suas lavouras". (...) Em resposta às gestões do deputado, afirmavam-lhe sempre que ali se encontravam congregados numa santa missão e que não possuíam intuitos de atacar ninguém; mas, se fossem atacados, não tinham remédio senão defender-se. Animando-os em sua fé renovadora continuava presente não só a crença na ressurreição dos que morressem na defesa da santa causa, mas também - como algo palpável - o Exército Encantado.

Na negociação com os sertanejos de Taquaruçu, o máximo que o deputado paranaense consegue é a promessa de que todos se dispersariam desde que também os de Caraguatá fizessem o mesmo. Na esperança de evitar o massacre, Correia Defreitas se dirige ao novo reduto, mas tem pouco tempo para fazer sua última tentativa. "Sabemos bem pouco do que acontece durante o encontro com os líderes, mas, de acordo com todas as fontes ... querem o fim do governo dos coronéis" (GENNARI, 2007, p.47). Sem atingir seu objetivo, o deputado começa o caminho de volta e chega em Campos Novos em 10 de fevereiro de 1914, de onde parte de trem em direção a Porto Alegre.

O sítio Porto União da Vitória apresenta uma cronologia da Guerra do Contestado ${ }^{35}$ onde em janeiro de 1914 os líderes dos fanáticos resolvem receber a comitiva republicana de paz em Taquaruçu, composta pelo deputado federal Manoel Correia de Freitas, coronel Henrique Rupp, coronel Antônio Rocha Tico e três parentes confinados no reduto. Como não chegam a um acordo, a comitiva retira-se do reduto decepcionada, sabendo que ainda morreria muita gente inocente. Porém Henrique Rupp e Lebon Regis não acompanham Correia Defreitas, Rocha Tico e os três guias ao reduto de Taquaruçu. Em março de 1914 - a nova comitiva republicana de paz encontra-se na vila de Perdiz Grande, onde entram em contato com um dos fanáticos, marcando uma reunião pacífica. A comitiva era composta pelo deputado federal Manoel Correia de Freitas,

35 Disponível em http://www.portouniaodavitoria.com.br/contestado/cronologia-da-guerra-do-contestado/. Acesso em 13.novembro.2016. 
os capitães Adalberto, Lebon Régis e Matos Costa. Outra vez, a comitiva retira-se decepcionada com a missão de paz, pois não chegam a um acordo. Porém, Correia Defreitas deixa a região contestada em 13 de fevereiro de 1914 e segue para o Rio Grande do Sul, portanto ele não estava presente nessa comitiva de paz enviada à vila de Perdiz Grande. 0 sítio destaca o deputado paranaense como uma das principais personagens do Contestado na categoria "autoridades".

No sítio do jornal Correio do Norte de Canoinhas há uma edição comemorativa ao centenário da Guerra do Contestado (CORREIO DO NORTE, 2012). ${ }^{36}$ A parte referente à comitiva republicana de paz onde aparece Correia Defreitas contém literalmente as mesmas informações do sítio Porto União da Vitório descrito acima.

No blog Caboclos Rebeldes ${ }^{37}$ temos o trabalho de Ricardo de Campos (2016) que também lembra a passagem de Correia Defreitas por terras contestadas. Destaca que o comandante Aleluia Pires não via os sertanejos como inimigos, mas sim como vítimas dos coronéis da Guarda Nacional que eram os chefes políticos dos municípios. Como encontrava-se adoentado, Aleluia Pires orienta ao capitão Nestor Passos, que o substituiria, que permanecesse nas cercanias até conseguir a dispersão dos sertanejos "mesmo que a missão de paz do deputado federal Correia Defreitas fracasse! ... Mas todos estão torcendo para que ele consiga convencer aquela gente a abandonar o reduto e voltar para suas casas." A missão de Correia Defreitas era apaziguar os sertanejos e dispersá-los sem efusão de sangue, noticiava a imprensa da época. 0 autor finaliza comentando que embora o deputado tenha prometido terras, escolas, estradas e dinheiro, só ouviu como resposta o desejo de vingança pela matança ocorrida em Taquaruçu e o líder sertanejo Elias de Moraes chegou a lhe dizer que só haveria paz se o governo devolvesse a vida daqueles que pereceram no antigo reduto. Ao perceber que os sertanejos estavam inflexíveis, Correia Defreitas decidiu deixar a região (CAMPOS, 2016, p 230-231).

\section{CONSIDERAÇÕES FINAIS}

De acordo com o exposto acima, são poucas as informações específicas sobre a participação e a presença de Correia Defreitas em terras contestadas. A intenção que teria motivado o deputado a ter envolvimento direito com os sertanejos não foi abordada. Os dados

\footnotetext{
${ }^{36}$ Disponível em http://ieij.com.br/Atividades/contestado/100.Anos.Contestado.pdf. Acesso em 13.novembro.2016.

37 Disponível em http://caboclosrebeldes.blogspot.com.br/. Acesso em 13. Novembro. 2016.
} 
apontados não esclarecem os reais motivos que fizeram com que o deputado tomasse a iniciativa de partir para o sertão catarinense e o fato dele ser representante de um corpo político bem definido, o Congresso Nacional parece ser ignorado. 0 simples apontamento de que ele era defensor de ideias socialistas não é argumento suficiente para entender as reais motivações. Os trabalhos acabam reproduzindo as informações da obra de Mauricio de Queiroz (1977) e não avançam na análise dessa presença parlamentar federal na região. Duas fontes de pesquisa necessitam ser abordadas mais profundamente e relacionadas para se entender a posição do deputado paranaense: as publicações dos periódicos da época, sobretudo o Diário da Tarde, de Curitiba, que fez a cobertura oficial da missão de paz e os Anais da Câmara dos Deputados com os apartes e projetos de Correia Defreitas e a posição dos outros deputados na época. A partir da análise dessas fontes será possível perceber a verdadeira estratégia dessa missão: uma causa realmente humanitária ou a construção de uma imagem do conflito que justificaria a repressão e a ação impiedosa das forças legais sobre os sertanejos?

Uma última fonte de pesquisa com relação a missão pacifista de Correia Defreitas são as narrativas biográficas ${ }^{38}$ sobre sua trajetória. Nenhuma aprofunda a questão da Guerra do Contestado, apenas fazem menção à passagem do deputado paranaense em terras contestadas ressaltando a sua nobreza de espírito que o conduziu até o sertão e a coragem que teve ao travar contato direto com os sertanejos:

Missão perigosa a que se arrojou o deputado paranaense, pois poderia ser maltratado e até morto pelos caboclos ignorantes que o tomariam por espião do governo, Defreitas conseguiu, ousadamente, penetrar nos redutos de Perdizes, Taquaruçu e Caraguatá e ali falando, convencendo, evangelizando, pode-se dizer que tocando o coração dos ferozes, mas infelizes vítimas do abandono dos poderes públicos, para dispo-los a deporem as armas e a se dispersarem submetendo-se às autoridades legais. (SOTTOMAIOR, 1922, p. 12)

A imagem de Manoel Correia Defreitas estava associada a um imaginário republicano. De longa data era um defensor do Paraná na questão dos limites com Santa Catarina, era um sujeito que tinha uma atuação crítica na sociedade e com uma leitura diferenciada dos processos sociais, portanto com a Guerra do Contestado não seria diferente.

Muitas das causas da violência e repressão aos sertanejos estava na divergência entre a racionalidade republicana e o modo de vida caboclo compreendido como uma expressão de

38 Ver Apêndice no final desse trabalho. 
rusticidade e que deveria ser extirpada de maneira definitiva. 0 agrupamento dos sertanejos não se tratava de fanatismo, mas foi a alternativa, encontrada por eles, de marcar sua presença de forma efetiva diante da indigência material que a república não democrática instalada no Brasil impôs a esse grupo, de recuperar seu estatuto de homem e manter sua identidade.

\section{REFERÊNCIAS}

ALBUQUERQUE, Mario Marcondes de (1987). Contestado: distorções e controvérsias. Curitiba: Estante Paranista № 30/Instituto Histórico e Geográfico do Paraná. Editora LíteroTécnica.

AURAS, Marli (1984). Guerra do Contestado: a organização social da irmandade cabocla. Florianópolis: Editora da UFSC/SP: Editora Cortez.

CAMPOS, Ricardo de (2016). Caboclos rebeldes: uma aventura pela Guerra do Contestado. Canoinhas: [s.n]. Disponível em http://caboclosrebeldes.blogspot.com.br/. Acesso 13.novembro.2016.

CARDOSO, Luiz Muricy (2014). “A guerra do fim dos tempos”. IN: Revista Leituras da História, № 74, p.20-25.

CARVALHO, Tarcísio Motta (2009). Coerção e consenso na Primeira República: a Guerra do Contestado (1912-1916). Niterói: Doutorado em História da UFF.

CORREA, Amélia Siegel (2006). Imprensa e política no Paraná: prosopografia dos redatores e pensamento republicano no final do século XIX. Curitiba: Mestrado em Sociologia UFPR.

CORREIO DO NORTE (2012). 100 anos do Contestado: Santa Catarina nunca mais foi a mesma. Canoinhas: Edição Especial de Dezembro. Disponível em http://ieij.com.br/Atividades/contestado/100.Anos.Contestado.pdf. Acesso 13.novembro.2016.

DALFRÉ, Liz Andreá (2014). Outras narrativas da nacionalidade: o movimento do Contestado. Curitiba: SAMP.

DERENGOSKI, Paulo Ramos (1986). 0 desmoronamento do mundo jagunço. Florianópolis: FCC.

DERENGOSKI, Paulo Ramos (2013). A sangrenta Guerra do Contestado. Florianópolis: DIOESC. 
ESPIG, Márcia Janete (2012). Carlos Magno e o Contestado. IN: Revista de História, $09 / 10 / 2012$.

FELIPPE, Euclides J. (1995). 0 último jagunço: folclore na história da Guerra do Contestado. Curitibanos: Universidade do Contestado.

GENNARI, Emílio (2007). As guerras sertanejas de Canudos e Contestado. Disponível em http://docplayer.com.br/9020294-Emilio-gennari-as-guerras-sertanejas-de-canudos-econtestado.html. Acesso em 13.novembro.2016.

HERCILIO, Antonio (1912). Excertos de um escrito inédito (continuação). IN: Almanaque da Revista A Casa do Lavrador da Secretaria de Agricultura, Indústria e Commercio para 1913. Anno I. Curitiba: Typographia da Penitenciaria, p. 170-174.

LAZARIN, Katiuscia Maria (2005). Fanáticos, rebeldes e caboclos: discursos e invenções sobre diferentes sujeitos na historiografia do Contestado (1916-2003). Florianópolis: Mestrado em História da UFSC.

LUZ, Aujor Ávila da (1999). Os fanáticos: crimes e aberrações da religiosidade dos nossos caboclos (contribuição para o estudo de antropossociologia criminal e da história do movimento dos fanáticos em Santa Catarina. Florianópolis: Editora da UFSC.

MARCELLINO, Walmor (2005). A guerra camponesa do Contestado. Curitiba: Quem de Direito.

MACHADO, Paulo Pinheiro (2001). Um estudo sobre as origens sociais e a formação política das lideranças sertanejas do Contestado, 1912-1916. Campinas: Tese Doutora História da UNICAMP.

MACHADO, Paulo Pinheiro (2004). Lideranças do Contestado: a formação e a atuação das chefias caboclas (1912-1916). Campinas: Editora da UNICAMP.

MARÉS DE SOUZA, Fredericindo (1978). Eles não acreditavam na morte: romance dos tempos dos fanáticos do Contestado. Curitiba: Estante Paranista № 8/Instituto Histórico e Geográfico do Paraná.

MARÉS DE SOUZA, Fredericindo (1987). o presidente Carlos Cavalcanti e a revolta do Contestado. Curitiba: Estante Paranista № 29/Instituto Histórico e Geográfico do Paraná. Editora Lítero-Técnica.

MARGARIDO, Alfredo (1974). "A reciprocidade no seio de um movimento camponês do sul do Brasil". IN: RANDLES, W.G.L et all. Para uma história antropológica. Lisboa: Edições 70, p.6173.

MENDONÇA, Maí N., HLADCZUK, Ana Maria (1992). Augusto Stresser e a Ópera Sidéria. Curitiba: Fundação Cultural de Curitiba, Boletim Informativo da Casa Romário Martins, v.19, $\mathrm{n}^{\circ} 99$. 
MIRANDA, Alcibíades (2012). Contestado. 2ª edição. Curitiba: Estante Paranista № 28/Instituto Histórico e Geográfico do Paraná.

MOCELLIN, Renato (1989). Os guerrilheiros do Contestado. SP: Editora do Brasil.

MOCELLIN, Renato (2015). Pelados x peludos: o massacre dos xucros. Curitiba: SITE.

MUZZI, Amanda (2006). Os jacobinos e a oposição à Prudente de Moraes na transição entre as presidências militar e civil (1893-1897). Rio de Janeiro: Mestrado em História a PUCRJ.

OLIVEIRA, Fernando Osvaldo de (1978). 0 jagunço: um episódio da Guerra do Contestado. Florianópolis: IOESC.

PIAZZA, Walter (1985). Dicionário Político Catarinense. Florianópolis: Assembleia Legislativa do Estado de Santa Catarina.

QUEIROZ, Mauricio Vinhas de (1977). Messianismo e conflito social: a guerra sertaneja do Contestado 1912-1916. SP: Editora Ática.

QUEIROZ, Suely Robles Reis de (1986). Os radicais da república. Jacobinismo: ideologia e ação (1893-1897). SP: Editora Brasiliense.

RIBEIRO, Naiara dos Santos Damas (2004). Como moléculas da humanidade: a presença de Correia Defreitas na Guerra do Contestado (1914). Curitiba: $12^{\circ}$ EVINCI (Evento de Iniciação Científica) da UFPR.

RODRIGUES, Rogério Rosa (2012). Imagens do Front: Canudos e Contestado e a fotografia de guerra. Teresina: ANAIS do VI Seminário Nacional de História Cultural - Escritas da História: ser-sentir-narrar.

SALOMÃO, Eduardo Rizzatti (2012). A Guerra de S. Sebastião (1912-1916): um estudo sobre a ressignificação do mito do rei encoberto no movimento sociorreligioso do Contestado. Brasília: Doutorado em História UNB.

SANTOS, Silvio Coelho dos (2006). O Contestado na historiografia e na literatura. Florianópolis: Coleção № 30 da Academia Catarinense de Letras.

SCHEIFER, Bruna (2008). Paranaguá, cidade portuária: entre a cidade "sonhada e a cidade real". Marechal Cândido Rondon: Mestrado em História UNIOESTE.

SERPA, Elio (1999). A Guerra do Contestado (1912-1916). Florianópolis: Editora da UFSC.

SOTTOMAIOR, Sebastião Paraná (1922). Paranaenses ilustres. Curitiba: [s.l].

THOMÉ, Nilson (2005). Breve história da Guerra do Contestado. Caçador/SC: UNC Campus Caçador. 
THOMÉ, Nilson (1999). Os Iluminados: personagens e manifestações místicas e messiânicas no Contestado. Florianópolis: Editora Insular.

TOKARSKI, Fernando (2002). Cronografia do Contestado: apontamentos históricos da região do Contestado e do Sul do Paraná. Florianópolis: IOESC.

TOTA, Antonio (1983). A guerra do novo mundo. SP: Brasiliense.

VALENTINI, Delmir José (2003). Da cidade santa à corte celeste: memórias de sertanejos e a Guerra do Contestado. Caçador: UNC.

VASCONCELLOS, Auro Sanford de (2008). Chica Pelega: a guerreira de Taquaruçu. $2^{\text {a }}$ edição. Florianópolis: Editora Insular.

WEINHARDT, Marilene (2002). Mesmos crimes, outros discursos: algumas narrativas sobre o Contestado. Curitiba: Editora da UFPR.

WOITOWICZ, Karina Janz (2014). Imagem contestada: a Guerra do Contestado pela escrita do Diário da Tarde (1912-1916). Ponta Grossa: Editora UEPG. 


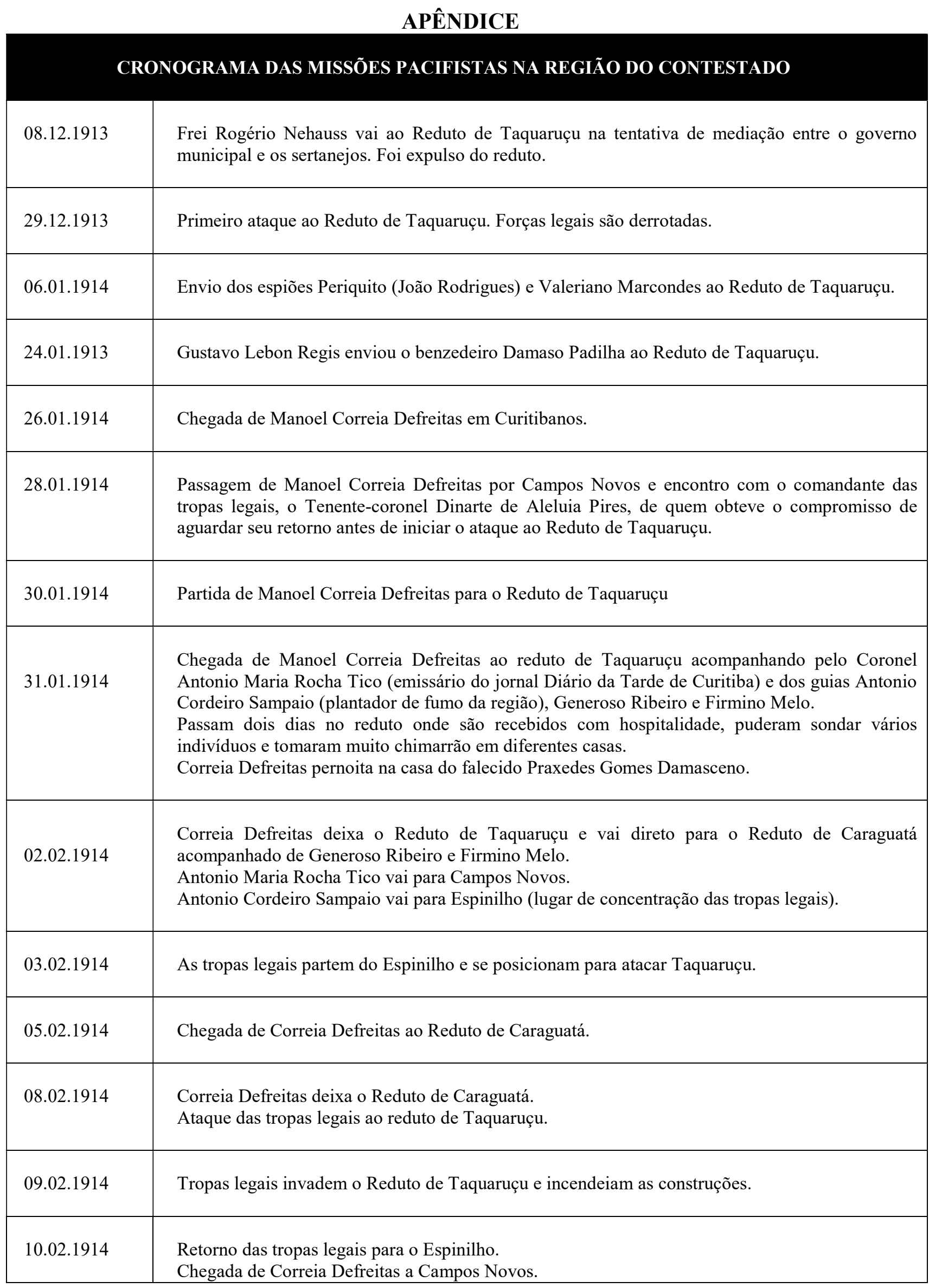




\begin{tabular}{|l|l|}
\hline 13.02 .1914 & Partida de Correia Defreitas para Porto Alegre. \\
\hline 14.02 .1914 & Tropas legais se posicionam para atacar o Reduto de Caraguatá. \\
\hline 08.03 .1914 & Combate de Caraguatá \\
\hline
\end{tabular}

FONTE: todas as referências citadas ao longo do artigo 
Relação das narrativas biográficas de Manoel Correia Defreitas analisadas para esse trabalho

\begin{tabular}{|c|c|c|}
\hline ANO & AUTOR & REFERÊNCIA COMPLETA \\
\hline 1921 & $\begin{array}{l}\text { Centro Cívico de Ponta } \\
\text { Grossa }\end{array}$ & $\begin{array}{l}\text { A VANGUARDA (1921). Sob a invocação do Tiradentes impõe-se a } \\
\text { reparação histórica Pró Correia Defreitas. Ponta Grossa, } 21 \text { de } \\
\text { abril de } 1921, \text { p.1-4. }\end{array}$ \\
\hline 1922 & Sebastião Paraná & $\begin{array}{l}\text { SOTTOMAIOR, Sebastião Paraná de Sá (1922). Manoel Correia } \\
\text { Defreitas. IN: Galeria Paranaense: notas biográficas. Curitiba: } \\
\text { Livraria Mundial, 1922. (Edição comemorativa do } 1^{\circ} \text { centenário da } \\
\text { Independência do Brasil), p. 51-60. }\end{array}$ \\
\hline 1927 & Ao Povo Paranaense & $\begin{array}{l}\text { POVO PARANAENSE (1927). Manifesto político AO POVO } \\
\text { PARANAENSE de fevereiro 1927. Curitiba: mimeo. }\end{array}$ \\
\hline 1927 & O Dia & $\begin{array}{l}\text { O DIA (1927). Candidatos avulsos: Correia Defreitas e Niepce da } \\
\text { Silva. Curitiba, O dia de } 24 \text { de fevereiro de } 1927 .\end{array}$ \\
\hline 1928 & Francisco Negrão & $\begin{array}{l}\text { NEGRÃO, Francisco (1928). Genealogia Paranaense. } 3^{\circ} \text { volume. } \\
\text { Curitiba: }[\text { s.n], p. } 375-392 .\end{array}$ \\
\hline 1948 & Saboia Cortes & $\begin{array}{l}\text { CORTES, José Correia Saboya (1948). “Os grandes vultos de } \\
\text { Paranaguá e de outros tempos: Manoel Correia de Freitas". IN: } \\
\text { Marinha - Revista do Litoral Paranaense, } N^{\circ} 79 .\end{array}$ \\
\hline 1951 & Nascimento Junior & $\begin{array}{l}\text { NASCIMENTO JUNIOR, Vicente Montepoliciano (1951). Correia } \\
\text { Defreitas: sua vida e obra. Paranaguá: Homenagem da Prefeitura } \\
\text { Municipal de Paranaguá ao transcurso de seu centenário. }\end{array}$ \\
\hline 1951 & Faria Rocha & $\begin{array}{l}\text { ROCHA, Augusto Faria (1951). O centenário de Manoel Correia de } \\
\text { Freitas. IN: Boletim do Instituto Histórico e Geográfico do Paraná, } \\
\text { Volume V, Fascículos 3-4, Julho-Dezembro, p.3-16. }\end{array}$ \\
\hline 1972 & Saboia Cortes & $\begin{array}{l}\text { CORTES, José Correia Saboya (1972). Os grandes vultos de } \\
\text { Paranaguá de outros tempos: Manoel Correia Defreitas. IN: } \\
\text { Boletim do IHGP, volume XVII, p.201-206. }\end{array}$ \\
\hline 1978 & Maria Nicolas & $\begin{array}{l}\text { NICOLAS, Maria (1978). Correia Defreitas. IN: O Paraná na Câmara } \\
\text { dos Deputados (1853-1977). Curitiba: [s.n], p. 67-68. }\end{array}$ \\
\hline 2013 & O Paraná & $\begin{array}{l}\text { O PARANÁ (2013). Não quis ser governador do Paraná: Freitas teve } \\
\text { a chance de governar dois estados, mas recusou. Podia ser rico e } \\
\text { preferiu ser pobre. O Paraná, } 5 \text { de maio de } 2013 \text {. Disponível em } \\
\text { https://www.oparana.com.br/variedades/nao-quis-ser-governador- } \\
\text { do-parana-30809/. Acesso } 22 . a b r i l .2014 . \\
\text { Disponível também em: } \\
\text { SPERANÇA, Alceu (2015). "Manoel Correia de Freitas: não quis ser } \\
\text { governador" IN: Famílias, fortunas \& façanhas: clãs e } \\
\text { personalidades que dominaram o Paraná. Cascavel: Projeto } \\
\text { Livrai-Nos! Artigos publicados pelo jornal O Paraná de } 02.12 .2012 \\
\text { a } 01.02 .2015, \text { p. } 135-140 .\end{array}$ \\
\hline
\end{tabular}

